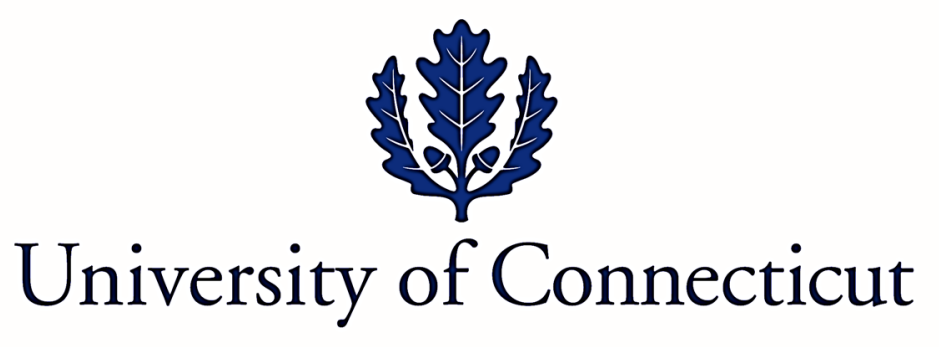

Department of Economics Working Paper Series

Do More School Resources Increase Learning Outcomes?

Evidence from an extended school-day reform

by

Jorge M. Agüero

University of Connecticut

Marta Favara

University of Oxford

Catherine Porter

Lancaster University

Alan Sánchez

Group for the Analysis of Development

Working Paper 2021-06

April 2021

365 Fairfield Way, Unit 1063

Storrs, CT 06269-1063

Phone: (860) 486-3022

Fax: (860) 486-4463

http://www.econ.uconn.edu/

This working paper is indexed in RePEc, http://repec.org 


\title{
Do More School Resources Increase Learning Outcomes? Evidence from an extended school-day reform
}

\author{
Jorge M. Agüero (University of Connecticut) \\ Marta Favara (University of Oxford) \\ Catherine Porter (Lancaster University)
}

Alan Sánchez (Group for the Analysis of Development) 


\begin{abstract}
$^{1}$
Whether allocating more resources improves learning outcomes for students in low-performing public schools remains an open debate. We focus on the effect of increased instructional time, which is theoretically ambiguous due to possible compensating changes in effort by students, teachers or parents. Using a regression discontinuity approach, we find that a reform extending the school day increases math test scores, with a large effect size relative to other interventions. It also improved reading, technical skills and socio-emotional competencies. Our results are partly explained by reductions in home production by students, specialization by teachers and investments in pedagogical assistance to teachers.
\end{abstract}

Keywords: Extended school-day reform, Jornada Escolar Completa, JEC, Peru, Young Lives

JEL codes: I2, I22, I26

\title{
Corresponding author:
}

Jorge M. Agüero

University of Connecticut

365 Fairfield Way, U-1063

Storrs, CT 06269-1063

United States of America

Email: jorge.aguero@uconn.edu

\footnotetext{
${ }^{1}$ We would like to thank the personnel of the Ministry of Education in Peru for facilitating access to the data and for answering all of our questions about the Jornada Escolar Completa and providing useful comments. We thank Alessandra Hidalgo and Andrea Cornejo for excellent research assistance. A previous version of this study by Aguero was supported by GRADE/FORGE. Favara, Porter and Sanchez were supported by ESRC/GCRF. We thank seminar participants at the Universidad del Pacífico, the Midwest Economic Development Conference, the Group of Development Analysis, UConn Neag School of Education, the Inter-American Development Bank, Newcastle University and Lancaster University.
} 


\section{Introduction}

In many settings, including education, more time on task should raise output. However, when it comes to public schooling this assumption is often challenged (Rivkin and Schiman, 2015) and there is a long-standing debate on whether more instructional time translates into better learning outcomes. ${ }^{2}$ Earlier theoretical models assumed that allocating more time to "study" increases human capital (Ben-Porath, 1967). More recent work has shown that students and teachers could alter their effort negatively in response to an increase in instructional time (Levin and Tsang, 1987; Todd and Wolpin, 2003). Empirically, the evidence is mixed, and it has been difficult to isolate the effect of extending instructional time from other factors. ${ }^{3}$ Despite this, it has become part of recommended policy. For example, more instructional time is part of the "No Excuses" model used in charter schools in urban areas of the United States. ${ }^{4}$ Similarly, an increasing number of developing countries are expanding the length of the school day in their public schools (Holland et al., 2014). Yet, in these countries, there is a much higher opportunity cost of extending the school day. They have smaller local and national education budgets and their school systems have lower levels and quality of complementary inputs.

We use a regression discontinuity approach to measure the impact of a extended schoolday reform in Peru. Peru is an upper middle-income country that consistently performs at the bottom of international standardized tests such as PISA (Programme for International Student Assessment). In every PISA round, the country has had one of the lowest shares of top performers (only one percent in 2018) and very high shares of low achievers (more than double the average OECD share). This low performance is confirmed by local national standardized tests, such as the one used in our study. For example, 85 percent of 8th graders are below grade-level in reading and a quarter of students are at least two grades behind. In order to reverse these outcomes, in 2015, Peru introduced the Jornada Escolar Completa (or JEC). The program's main goal was to add two

\footnotetext{
${ }^{2}$ See Jackson (2020) for a debate on whether financial resources to public schools can improve child outcomes in general. See also Glewwe and Muralidharan (2016) for a more ample discussion relevant to developing countries. ${ }^{3}$ Cross-country studies (Lee and Barro, 2001; Wössmann, 2003) and those using state-level data within the United States (Card and Kruger, 1992) tend to find no relationship between time spent in school and learning or labor market outcomes. See Rivkin and Schiman (2015) for a recent assessment of micro-level studies in advanced economies exploring a longer school year.

${ }^{4}$ See Angrist et al (2013) for a discussion on how time in school compares to the impact of less traditional elements of the No Excuses model. See also Dobbie and Fryer (2013) and Fryer (2014) for additional analysis.
} 
pedagogical hours per day in 1,000 high schools nationwide to match the number of instructional hours in private schools, which tend to have better learning outcomes.

Selection into the program was decided by the national government. Critical to our identification strategy, schools with eight or more secciones, the equivalent to homerooms in the United States, have a discontinuously higher probability of participating in the program compared to schools with seven secciones or less. At the threshold, the probability to be part of the program goes from near zero to almost 50 percent. As explained in section 2 below, this cutoff is arbitrary and was selected due to budgetary reasons. Smoothness tests applied to a large set of preintervention variables help validate the arbitrariness of the threshold. The program was announced at the end of the 2014 school year and the rules were based on data from the 2013 school year, making it impossible for schools to manipulate the assignment variable and affect their participation into the program.

Using administrative data and a fuzzy regression discontinuity approach, we find that participating in JEC increased math and reading scores measured by the national standardized test conducted at the end of the first year of intervention. The effects are larger and more robust in math where we document an increase of around 23 percent of a standard deviation. Using a household survey, we show that the program also increased socio-emotional competencies and technical skills (e.g., knowledge of English, access to digital devices).

Our results are larger than those observed in other developing countries. Lavy (2015) uses cross-country data (PISA) from 50 countries to show that one additional instructional hour in a given subject (mathematics, science or language) improves test scores by $0.06 \mathrm{SD}$ of the test score distribution in that subject, holding overall instructional time constant. However, the effect falls to 0.025 SD for developing countries (see also Rivkin and Schiman, 2015). A small body of evidence on specific extended school-day reforms in low and middle-income countries shows small effects up to a tenth of a standard deviation improvement in test scores (Cabrera-Hernández 2020; CerdánInfantes and Vermeersch 2007; Bellei 2009; Orkin 2013; Hincapie 2016). However, Padilla-Romo (2017) argues that in many of these country-specific studies it has been difficult to isolate the causal effect of the reforms.

While an exhaustive list of reasons for the positive (and larger) effect of the $J E C$ is beyond the scope of this paper, we explore several channels. A common theoretical concern with the effectiveness of extending the school day is a possible negative change in behavior (Levin and 
Tsang, 1987; Todd and Wolpin, 2013). For instance, teachers and students could reduce their effort per hour to keep the total amount of effort the same despite the increase in instructional hours. Parents could change their behavior too by helping their children less now that they have longer hours at school. This crowding-out behavior has been observed in other scenarios, for example, in response to attending better schools (Pop-Eleches and Urquiola, 2013) and receiving anticipated school grants (Das et al, 2013).

We find no evidence of these negative behaviors. Using a large student survey, we found no change in parental involvements such as them talking to their children, helping them with homework, explaining school topics or caring about their children's grades (all as reported by students). When asked about their perceptions in math and reading, students in JEC do not exhibit a lower self-perception in these subjects. This contrasts with the negative finding in selfperceptions when students attend better schools (e.g., Pop-Eleches and Urquiola, 2013). We do not find a major behavioral effect from teachers either. However, using a national survey of teachers, we do find a reduction in the number of courses taught. This implies that specialization was an important component of the success of the program.

A second mechanism we explore is the students' reallocation of time. For instance, students could compensate longer school hours by reducing the amount of time they spend studying at home and on household responsibilities. Using the household survey and the fuzzy RD approach, we document a two-hour increase in time spent at school for students in JEC, which coincides with the two additional hours imposed by the program. This increase came at the costs of time allocated to household chores, other domestic tasks, leisure and sleeping. However, we find no reduction in studying at home. The substitution in time away from home production and leisure but in favor of time on task (at school and home combined) partly explain our results.

Our last mechanism focuses on the role of pedagogy and the provision of the additional inputs. Mbiti et al (2019) show that in developing countries simply augmenting school resources may have limited impact on learning outcomes because of the complementarities with other inputs who are not improved at the same time. A novelty of JEC was that the expansion in the length of the school day was accompanied by support in pedagogical assistance to teachers and informationtechnology to the school overall (e.g., language lab for English instruction). Through the analysis of administrative data, we document a clear impact of the program on the amount of pedagogical support received by JEC schools. We also show an increase in access to computers as well as an 
increase in support staff such as having a school psychologist and a school guard. The latter helps explain the positive impact on socio-emotional skills.

Our work contributes to the recent literature on improving learning outcomes in developing countries which has focused almost exclusively on solutions that bypass public school investments. Our focus on a program that tries to improve school learning by adjusting how the service is provided within public schools in developing countries offers a complementary view to work showing an improvement in learning outcomes from outsourcing the running of schools to the private sector (Romero et al, 2020; Barrera-Osorio et al, 2020), by reallocating children to private or more selective public schools (Aguirre, 2020; Angrist et al., 2002, 2006; Muralidharan and Sundaaraman, 2015) or by investing in learning activities outside of school time (Muralidharan et al., 2019). Our results have comparable impact sizes and offer results that show that it is possible to improve learning outcomes within the public sector too. Our paper is also related to studies that have explored the expansion of the school year (e.g., Prinduri, 2014; Agüero and Beleche, 2013), the debate regarding year-round school calendars (e.g., McMullen and Rouse, 2012) as well as grade retention (e.g., Tafreschi and Thiemann, 2016; Manacorda, 2012).

In the next section, we describe the program structure and timetable, then outline our data sources in section 3. In section 4 we explain the identification strategy, then present results and explore mechanisms of impact in section 5, accompanied by an exhaustive set of robustness checks. We conclude in the final section.

\section{Expanding the school day: Peru's Jornada Escolar Completa}

In Peru, prior to college, students attend elementary school (grades 1-6) and then high school (711) where the school calendar for public schools runs from mid-March to mid-December. ${ }^{5}$ For the 2015 academic year, Peru expanded the length of the school day in 1,000 public high schools nationwide as part of the new program called the Jornada Escolar Completa (JEC). Schools in this program added two pedagogical hours per day to their schedule making a total of 45 hours per week. ${ }^{6}$ The program's goal was to improve not just the quantity of schooling hours but also the quality of the education service provided by public schools and to replicate some of the features observed in private schools. For instance, relative to regular public high schools, JEC schools

\footnotetext{
${ }^{5}$ Private schools have a longer calendar and tends to start two weeks earlier.

${ }^{6}$ A pedagogical hour is 45 minutes long.
} 
benefit from: (i) a pedagogical component, which includes accompaniment for teachers and students, teaching of English for students, and education for work for students; (ii) improved school management (more and better organized school personnel); (iv) improved physical infrastructure; and, (v) improved IT support (MINEDU 2014). Teachers' and principals' salaries increased to account for the additional hours and online support was offered to subject coordinators as part of the program. ${ }^{7}$

In the regular system, math and reading are each allocated four (pedagogical) hours per week. Under JEC, math is increased to six hours and reading five. English added three hours (from 2 to 5 ) and science two (from 3 to 5). ${ }^{8}$ Also, the program paid special attention to tutoring students, especially for those found to be lagging behind. All other subjects either stayed the same or added an hour with JEC. ${ }^{9}$

The program was designed to be implemented only in public high schools and eligibility required schools to have only a morning shift (so that the expansion would not affect afternoonattending students) and to be large enough: have eight or more "sections" and available space to accommodate, for example, a laboratory and a library. Personnel at the Ministry used data from the 2013 Censo Escolar (school census) to identify the list of schools that satisfied all these requirements and found 1,360 schools nationwide. Schools that are recognized as "emblematic" were also added to the list (52 schools), despite not necessarily satisfying all the requirements. ${ }^{10}$

Relevant to our identification strategy is the selection of schools with eight or more "sections". A section is the equivalent of a "homeroom" in the United States. The smallest (full or complete) high school in Peru will have five sections: one per grade. However, bigger schools would have two or more sections per grade so the number of sections tends to be a multiple of

\footnotetext{
${ }^{7} \mathrm{JEC}$ had no significant provisions of meals as part of its design. Peru's public schools do not provide meals to students, except for breakfast in extremely poor districts and only in pre-K to 6 grade schools as part of the Qali Warma program. Only high schools in indigenous communities in the Amazon are part of this program, which are not part of JEC.

${ }^{8}$ Table A1 in the Appendix shows the detailed comparison of hours per subject, as established by Ministry of Education, in the "Simple" system (column 1) and JEC (column 2).

${ }^{9}$ However, note that schools in both the regular and the new system have unassigned hours $(6$ and 5 per week, respectively). In principle, nothing stops principals in schools that did not participate in JEC to allocate those hours to math, reading or any other subject. If that were the case and assuming JEC schools do not use unassigned hours in a similar fashion, our results would represent a lower bound of the impact of the increase in school hours, due to the possible "contamination" of the control group.

${ }^{10}$ Table A2 in the Appendix presents the detailed rules for selecting the high schools participating in JEC for 2015.
} 
five. ${ }^{11}$ Thus, the choice of eight sections is quite arbitrary, it is not a multiple of five and helps us with the identification assumptions of smoothness around this threshold. Also, while not formally discussed in the directive creating the program, the choice of eight sections reflects the budgetary limits of JEC in its first year. As discussed later, the main source of identification comes from comparing schools around this threshold as the probability of participating in JEC changes discontinuously at eight sections.

The list containing 1,412 schools $(=1,360+52$ emblematic $)$ was then sent to local coordinators who validated it. This process added and removed some of the schools selecting a total of 1,343. The Ministry then hired evaluators to obtain further information about these schools and selected 1,000 of them. This list was included in the directive creating the program in September of 2014 (RM N 451-2014-MINEDU). The list was amended one more time in February of 2015 replacing six schools from the original list (RM N ${ }^{\circ}$ 062-2015-MINEDU). Note that going from the original 1,412 schools to the final list of 1,000 schools is driven by unobservable characteristics, possibly reflecting the bargaining between the central administration and the local coordinators and school districts. Thus, to causally identify the impact of the program we avoid comparing the left-out schools with the final list. Rather, in this paper we use the first set of rules as they depend on clear guidelines obtained from observables: schools with eight or more sections. The data sources and the methodology to identify causal effects are described next.

\section{Data}

We use three administrative data sources, a survey of teachers and the Young Lives panel dataset of individuals to estimate the effect of the JEC programme on test scores and the mechanisms explaining it. All datasets, except for Young Lives, come from the Ministry of Education. The main source of information is the 2015 Evaluación Censal de Estudiantes de Secundaria (ECES). ECE-S is the national standardized test administered to all eighth graders in public and private schools nationwide. The 2015 ECE-S, the first of its kind, has a coverage of 94.4 percent of

\footnotetext{
${ }^{11}$ A high school with eight sections would have at least one section per grade and three grades with two sections each. The assignment of students to sections is not regulated by the Ministry of Education (MINEDU) and varies by school. In some cases, it would reflect tracking of students but in others depends on alphabetical order or other rules. Relevant to our empirical strategy, we do not expect the assignment to discontinuously change in high schools with eight sections. We cannot test for this hypothesis because the MINEDU does not collect this information. Furthermore, personnel at the MINEDU do not think such a discontinuity exist at the threshold of eight sections.
} 
students and 99.5 percent of high schools. This standardized test, applied at the end of the school year (17 and 18 of November of 2015), consists of 60 multiple choice questions in math and reading, respectively. The $\mathrm{z}$-score transformation of the math and reading tests are our main variable of interest, using the national mean and standard deviation, which includes public and private schools. The Ministry classifies students into four groups depending on their performance in the test. In the highest group, students are at grade-level and are ready to face the challenges of the next grade. Only 14.8 percent of students achieve this level for reading and less than 10 percent in math. Students in the second group, "in process", partially obtained the goals for their grade but secured knowledge of the previous grade. Beginner-level students failed to show mastery of the previous grade and around 40 percent of 8 th graders scored at this level in each subject. Finally, 37.7 percent in math and 23.4 for reading are below the beginner-level. This dismal performance is consistent with the poor scores obtained by Peruvian students in international tests such as PISA or TERCE. Thus, in our analysis we also explore whether JEC affected the distribution of students by estimating the impact on the probability of scoring in the highest level.

The ECE-S included a short questionnaire where students were asked about their demographic and socioeconomic characteristics (e.g., age, gender, parents' education, native language). Relevant to our study, students were asked also about parental involvement regarding, for example, homework and book recommendations and their perception about their own abilities in math and reading. We use these variables to capture possible mechanisms. Finally, this questionnaire asked students about their perceptions regarding teachers. Unfortunately, these questions requested students to combine their views for their math and reading teachers. This limits the possibility to explore changes in teaching practices as results of JEC, separately by subject.

The second data source is the school census (Censo Escolar). This is a yearly administrative data that captures the characteristics of the school in terms of infrastructure, personnel and enrolment. This is complemented at the end of the year with passing rates. Unlike the ECE-S, the census contains data at the school or grade level but not at the student level. Also, this information is reported by the principal's office. The Ministry used these data to identify the original list of schools from which to select the ones receiving the JEC program. Thus, we use the same data, from 2013, to test for the smoothness assumptions to validate our identification strategy.

The third data source used in this paper is the Semáforo Escuela which allows us to examine the changes in school quality effected by the JEC program. Semáforo Escuela is a data system 
used by the Ministry of Education to monitor the delivery of educational services provided by public schools. Data is collected monthly (between April and November, except August) on a number of aspects, including characteristics of administrative and teachers staff, access to accompaniment for teachers and other programs run by the Government, access to IT, teachers level of specialization, etc. Each month, a representative sample of schools is selected and visited for this purpose. Information is provided by the principal (school module) and by up to 3 teachers per school, randomly selected (teachers' module). For our analysis, we aggregate data collected in 2015 and 2016 (if a school is visited twice, we choose the first observation).

The fourth data source is the National Survey of Teachers (Encuesta Nacional a Docentes, ENDO), a biannual survey administered to a representative sample of teachers from public and private schools. The survey collects information on teachers' professional trajectories, income, time use, access to training and IT, attitudes and motivation, among other aspects. Up to 3 teachers are randomly chosen per school. For our analysis we used data from ENDO 2016. This survey is currently discontinued.

Finally, we use data from a national sample of adolescents aged 12 years, the Peruvian younger cohort of the Young Lives study (YL), to extend the analysis of the effect of the JEC program on a set of child-level outcomes measured in 2016 that might, in turn, explain impacts on academic achievement: time use, socio-emotional competencies (measurements of self-concepts and aspirations) and technical skills (knowledge of English and digital skills). Children were selected at the age of 1 year from a random sample of 20 districts - sampled from the universe of district, excluding the 5\% wealthiest districts. The original sample was composed of 2,052 children, with 100 children per district. This cohort was first visited in 2002 (at the age of 1 year) and revisited at ages 5, 8, 12 and 15 in 2006, 2009, 2013 and 2016 (respectively). In the last visit, data on the name of the school attended by the adolescent was collected.

We used data from Semaforo Escuela, ENDO and YL to explore the potential mechanisms through which the JEC programme might have an impact on test score. Table A8 (Appendix) summarizes the information available from these data sources, unit of observation, and year in which the data was collected. As with ECE-S, these datasets are each linked with the 2013 school census to determine whether or not schools satisfy the JEC eligibility criteria. 


\section{Methodology}

We use the selection rules of the JEC program to implement a 2SLS approach. As described above, having eight sections or more increases the participation in JEC but does not fully explain it, which implies a fuzzy regression discontinuity design. Thus, we use discontinuity at eight sections as the instrument for participating in JEC as the first stage. This is shown by Equation (1) below:

$$
\mathrm{JEC}_{\mathrm{ij}}=\pi \mathbb{1}\left(\mathrm{S}_{\mathrm{j}} \geq 8\right)+\mathrm{h}_{1}\left(\mathrm{~S}_{\mathrm{j}} \geq 8\right)+\mathrm{h}_{2}\left(\mathrm{~S}_{\mathrm{j}}<8\right)+\theta \mathrm{X}_{\mathrm{ij}}+\mathrm{e}_{\mathrm{ij}}
$$

where $J E C_{i j}$ takes the value of one if student $i$ in school $j$ is part of JEC and zero otherwise. The indicator function $\mathbb{1}\left(\right.$.) returns a one only for schools that have eight sections or more $\left(S_{\mathrm{j}} \geq 8\right)$. Functions $h_{1}($.$) and h_{2}($.$) are flexible polynomials in the assignment variable S$ (number of sections) and $X$ is a vector of students' characteristics (age, sex, mother's language and school attainment) and about the school (e.g, urban/rural location and school district fixed effects). The second stage, estimating the impact of JEC (as predicted by the discontinuity) on outcome $Y_{i j}$ is given by Equation (2) and captured by parameter $\beta$ :

$$
\mathrm{Y}_{\mathrm{ij}}=\beta \widehat{E} \widehat{E C}_{\mathrm{ij}}+\mathrm{h}_{1}(\mathrm{~S} \geq 8)+\mathrm{h}_{2}(\mathrm{~S}<8)+\lambda \mathrm{X}_{\mathrm{ij}}+\mathrm{u}_{\mathrm{ij}}
$$

Standard errors are heteroskedasticity-robust and clustered at each of the 215 local school districts (known as UGEL). ${ }^{12}$ Our identification strategy relies on two assumptions discussed in the next subsections.

\subsection{First stage}

For the instrument to be valid, the discontinuity at eight sections should strongly predict participation into JEC. As discussed in section 2, and in particular, given the set of requirements listed in Table A2, the Ministry used data from 2013 to identify the schools that had eight or more sections as part of the decision process. In Figure 1 we provide visual evidence to validate such a rule. As expected, the probability that a public high school is part of JEC is zero for those with less than seven sections and near zero for those with seven sections (one percent). At eight sections, the probability discontinuously jumps to nearly 50 percent and remains high before decreasing for

\footnotetext{
${ }^{12} \mathrm{We}$ also explore an alternative clustering approach. Following Lee and Card (2008), when the running variable is discrete, as in our case, they propose clustering by the running variable. As shown below, our results do not change when using that approach (see Table 2). However, when we restrict the sample to schools with 7 and 8 sections, such a clustering approach would be invalid. Thus, we use the clustering by school as our preferred methods.
} 
very large schools. ${ }^{13}$ This feature implies a fuzzy discontinuity as the probability of been part of JEC is less than certain at the threshold. However, it provides the necessary evidence for an instrumental variables approach.

The regression counterpart of this evidence is presented in Table 1. In column 1, using all the public schools and with linear splines for the running variable, we find that at the threshold of eight sections, a school is 47.9 percentage points more likely to be part of JEC. Under the same specification but limited to urban schools, column 3, yields a $\pi$ parameter of 49.1 and when restricted the sample to schools with seven or eight sections (nationwide) the parameter implies an increase in 51.8 points (column 5). Using quadratic splines (columns 2 and 4) do not change our conclusions. That is, the rule of selecting schools based on eight sections is a strong predictor for JEC and provides a discontinuous jump that can be used as an instrument, as long as the exclusion restriction is satisfied.

\subsection{Smoothness tests}

To satisfy the exclusion restriction, the instrument should affect the outcomes only through its impact on the participation in JEC. Thus, for all other variables, and especially for those measured in 2013, there should be no discontinuity at the threshold. This is presented first, graphically, in Figure 2, and tested formally in Table A4 (Appendix).

The figure plots the average values of a set of predetermined variables grouping the sample of all public high schools by number of sections: start and end time of the schools, length of the school day, access to welfare programs, share of girl students enrolled, passing rates (all and by gender), use and teaching of indigenous language and whether the school has a morning shift only. The data come from the 2013 Censo Escolar, which reports information at the school level. It is easy to observe that for all the variables there is a smooth transition around the threshold of eight sections. These results confirm that the timing of the reform eliminates the possibility of manipulation of the assignment variable. As discuss in section 3, the initial selection of schools used the 2013 Censo Escolar. The rules for selection into JEC were devised in 2014 and made public in October of that year. Thus, schools were not able to alter the number of sections back at beginning of school year in 2013. Note, however, that there is an urban bias in JEC. The program mainly targeted urban schools in its first year and there is a discontinuous jump at the threshold

\footnotetext{
${ }^{13}$ Schools with more than 30 sections tend to have a morning and an afternoon shift and are less likely to be elegible.
} 
for this variable (Figure 2, Panel E). Thus, our results for the urban schools only are presented alongside the results for the full sample.

Figure 3 similarly shows student-level pre-determined characteristics by number of sections: age, gender, whether s/he attended kindergarten, repeated a grade as well as her/his mother's education and language. We show the same smooth transitions around the threshold for this set of variables. Appendix Table A5 provides the regression results reinforcing the validity of our identification strategy. The results of using a fuzzy RD to estimate the impact of JEC, via 2SLS, on academic achievement are presented in the next section.

\section{Results}

\subsection{Main findings}

We start with Figure 4, which shows the reduced-form graphs for the impact of JEC on test scores, using ECE-S data. In the top row, we consider two outcomes for reading: test scores and the probability that a student scores in the highest group (=1 if performed at grade level). In both cases, there is no evidence of a strong discontinuity for this subject. However, a jump is clearly observed for the math outcomes. These findings are validated in Table 2 using 2SLS.

For each of the four outcomes (i.e., test scores and probability of scoring in the highest level for math and reading) we consider four samples of public high schools. In column (1) all schools are considered. However, due to the urban bias of JEC, we restrict the sample only to schools in urban areas (column 2), to schools with a morning shift (column 3) and to schools in urban areas but with morning shift only (column 4). There is robust evidence that the effect is statistically different from zero for both math and reading.

The effects for math are large. The basic specification shows that JEC increased math test scores by 0.24SD (Panel C, column 1). Limiting the sample to urban schools with a morning shift (Panel C, column 4) shows that JEC increased the test scores by 0.23SD. Even our lower estimate is bigger than the effects reported by Bellei (2009) for Chilean high schools (0-0.12SD in math) and by more recent papers using data from PISA who tend to find an impact $<0.04$ SD for 
developing countries (Lavy, 2015 and Rivkin and Schiman, 2015). ${ }^{14}$ To put our results in a bigger context, in Figure A1 (Appendix), we compare them with the effects found in recent randomized controlled trials in education conducted in developing countries as reported by Kremer et al (2013). The lower (upper) bound of our results for math exceed 60 (95) percent of the effect size of studies reviewed by these authors.

\subsection{Further robustness checks}

We now consider additional robustness checks to the sample restrictions used above. We first explore alternative ways of clustering the standard errors. In Table 2 we presented the results with clustering at the school district in squared brackets. Following Lee and Card (2008) we also explore clustering by the discrete running variable, number of sections, and display them in curly brackets in the same table. Using this clustering option does not change our results.

We consider a local randomization $\mathrm{RD}$ approach given the discrete nature of the assignment variable. The identifying assumption is that in the vicinity of the cutoff, assignment is as good as random (Cattaneo, Idrobo and Titiunik, 2018). Table 3 shows nonparametrically identified estimates of the first stage (column 1) as well as the reduced forms (columns 2-5). These results confirm our previous findings: a strong effect for math and a weaker impact (but still positive) for reading.

We also explore the CDF in tests scores for math and reading of schools with seven sections against those in eight sections and limiting the sample to urban schools. This is shown in Figure A2. The results are consistent with those of Table 3. For reading, we do not find evidence of stochastic dominance. However, for math, the performance of students in schools with eight sections stochastically dominates those with seven sections, suggesting a clear effect of JEC on academic achievement.

We consider quadratic splines as an alternative specification, and the results are presented in Table A6, columns 1-4. Again, these modifications do not affect our conclusions.

We use an alternative identification strategy by exploiting an additional source of variation: public schools with shifts other than only-morning are not eligible for JEC. For them, there should

\footnotetext{
${ }^{14}$ Hincapie (2016) suggests that the expansion in Colombia led to an increase of at most 0.10SD for $9^{\text {th }}$ graders. In Mexico, Padilla-Romo (2017) reports near-zero effects in the first year of the implementation and up to 0.14SD four years after but for students in primary school (third to sixth graders).
} 
be no discontinuity at eight sections. Figure A3 (Appendix) validates that conjecture. Thus, we can use a difference-in-discontinuity approach and compare the discontinuity at the threshold in eligible and ineligible schools. This is done in Table A7. In column (2), when considering only urban schools, the impact of JEC on math test scores, Panel C, is 0.29SD.

As a final robustness check, we consider a placebo test using an alternative group of ineligible schools: private high schools. In Figure A4 (Appendix) we see that for these schools there are no discontinuities at the threshold of eight sections. Taken together, all these results suggest a strong and robust effect of JEC on math test scores but not on reading. In the next section, we discuss the impact of JEC on the behavior of parents, students and teachers.

We then repeat the analysis using the Young Lives data. Table A9 (Appendix) reports descriptive statistics for the balanced panel of children of Young Lives children tracked over 15 years that were attending school during the last visit (column 1). For the purpose of this analysis, we consider as the treatment group (Column 4) those children attending schools that were eligible for JEC since 2015, and children attending regular public schools as control group. ${ }^{15}$ In Young Lives data the learning outcomes are measured by Peabody Picture Vocabulary Test (PPVT), a reading comprehension test and a math test (Cueto et al., 2009; Cueto and León, 2012). ${ }^{16}$ Although this sample is not fully nationally representative, Young Lives produce very similar estimates of the JEC impact on math and reading test scores to ECE (by 0.25SD and 0.30SD, respectively).

\subsection{Mechanisms}

We proceed to analyse the potential mechanisms explaining the improvement in learning outcomes. To do this, we use other data sources and the same identification strategy to measure the impact of JEC on other dimensions of children and their educational environment. In all cases,

\footnotetext{
${ }^{15}$ There are 439 Young Lives children attending JEC schools, from which 355 attend schools that were eligible for JEC since 2015 , whereas 84 attend schools incorporated to JEC in 2016. Children from schools that were eligible for the JEC reform since 2016 are excluded for two (related) reasons. First, anecdotic evidence suggests that the transition to become a JEC school takes time, and it might occur that a school labelled as such in a certain year might not have all the features of a JEC school implemented. Second, even if schools were fully operational as JEC since the beginning of the school year (March-April), given that data collection took place between June 2019 and February 2020 the time elapsed between the implementation of the reform and the follow-up is very short for the JEC 2016 cohort.

${ }^{16}$ PPVT is designed to measure vocabulary knowledge. The test is composed of up to 125 items (in Spanish used adapted for Latin America (Cueto and Leon, 2012; Dunn et al. 1986)). In each item, the interviewer says a word to the child and from four pictures she must select the one that best represents the word heard. This instrument has been administered since Round 2 . In turn, the reading comprehension and math achievement test scores were developed by Young Lives to measure children and adolescents' achievement according to aspects they should know given their age and grade and have been administered since Round 3 . In this case, outcomes measure the total number of correct answers. For analysis, we used raw test scores standardized by age in years.
} 
we used data from 2016, about one year after the JEC program started operating. Those schools that became JEC in 2016 are dropped from the sample because in that year, a different eligibility rule was used. Each dataset was described in Section 3. When relevant, we created indexes to summarize our results. ${ }^{17}$

\section{Child's time use}

Students and parents might choose to exert a lower level of effort (for students, especially outside school), and this makes the net impact on time dedicated to learning activities ambiguous. ${ }^{18}$ Although pure effort is unobservable, we confirm that JEC has an overall positive impact on a child's time dedicated to study. Using data from Young Lives, in Table 4, we find that JEC increases time at school by 2.1 hours per day. This closely mirrors the increase in the length of the school day at JEC schools. This increase implied a reduction in time spent on almost all other activities, such as sleeping, household chores, domestics tasks, taking care of other household members, time spent studying at home, and leisure. We also find a reduction in the time spent studying at home, but it is comparatively small ( 0.1 hours per day).

\section{School resources}

As part of its design, JEC is also expected to increase the availability of school resources: IT infrastructure, staff, and the pedagogical resources available for both teachers and students. Our results, reported in Table 5, are consistent with improvements in all these areas by 0.8SD, 1.7SD, and 5.1SD respectively. The increase in IT infrastructure (Panel A) is explained by a larger number of classrooms with computers and laptops, and a higher probability that IT equipment receives

\footnotetext{
${ }^{17}$ Each index is the weighted average of a group of selected variables. Each of these variables is standardized with mean zero and variance equal to one. Prior to standardization, the order of the variables for which higher values reflect non-desirable results is reversed. When there are missing values and this is not due to filtering, we impute the average to the missing observation (two averages are considered, depending on whether the observation is from a school that has 8 sections or more or less than 8 sections).

${ }^{18}$ Todd and Wolpin (2003) show that in order to understand the full effect of education policies the behavioral changes of parents, students (and, indeed, teachers) should be incorporated. Recent work by Pop-Eleches and Urquiola (2013) has shown that behavioral responses are possible in the context of education. In Romania, the authors find that when children attend a better school, they feel marginalized, their parents reduce their efforts when helping them with homework and teachers sort themselves within the schools. Furthermore, they show that these negative behavioral changes tend to occur early on and after a few years the effects reduce or even vanished. Thus, one could expect similar behavioral changes with the expansion of the school day. For example, Levin and Tsang (1987) introduce a model of effort and show that if the previous length of the school day represented an equilibrium, extending the number of hours could bring no effect on test scores because of students and teachers could reduce their effort levels per hour of instruction.
} 
maintenance, though offset by a reduction in the probability the school has at least one computer lab and a Kit Robotica - this is a box that contains electronic components and materials used in interaction with a tablet to build 'robot' models. In relation to the school staff available (Panel B), the probability of having a complete teaching staff reduces, which could be an unintended consequence of JEC schools, which by definition had to hire additional teachers in the first years; However, this is compensated by an increase in the number of non-teaching staff available.

The increase in the availability of pedagogical resources (Panel C), arguably one of the most important features of the program, is explained by a significant increase in the likelihood of having a psychologist at the school-required in JEC but not regular schools - , having teachers that provide support to parents, and that the school participates in the MINEDU program "Acompañamiento pedagogico" - also a component of the JEC programme, though not unique to it. Schools that receive this programme are visited by specialists in pedagogy who work with teachers to improve their pedagogical strategies. In turn, psychologists work both with tutor teachers and (directly) with students.

\section{Teachers' behaviors}

We explore three possible changes in teachers' behaviors due to the program. First, we consider effects on time allocation. For instance, while teachers must teach longer hours, the net impact on other school-related activities inside and outside school (preparing lessons, grading students' homework, talking with parents, interacting with other teachers) is ambiguous. Teachers had an increase in their salary (compared to teachers in regular public schools), which might improve their motivation and effort if the substitution effect offsets the income effect.

In Table 6, we explore the impact of the program on teachers' time use inside and outside school (Panel A), attitudes and satisfaction (Panel B), and training and pedagogical practices (Panel C). We do not find evidence that JEC changed the overall time dedicated by the teacher to school activities (at his/her main school), but it increased the probability of spending time working in other activities, especially teaching in private schools, which is likely to be an unintended effect that might be explained by certain groups of just arrived teachers being in demand in nearby schools (e.g., English teachers, part-time teachers).

While there is no systematic evidence of changes in attitudes and satisfaction, our analysis uncovers changes in teacher pedagogical practices (Panel C) summarized by a change in the 
constructed index by $0.27 \mathrm{SD}$, explained by a higher level of teachers' specialization (decrease in the number of subjects taught by the teacher) and, again, an increase in the probability that the teacher receives support from "Acompañamiento pedagogico".

\section{Sorting effects}

Sorting effects of both teachers and students might also be relevant: better teachers might be more likely to apply for a position in JEC schools - due to the salary increase. Similarly, more involved parents might choose to transfer their children to JEC schools, and these children are likely to have better learning outcomes, generating positive externalities for the rest of students—in Peru, there are no legal restrictions for enrolment of children that do not live in the district where the school is located. We do not find evidence that any of these channels is taking place. In Table 6 (Panel D), we find no evidence that teachers' characteristics are different in JEC and non-JEC schools, which suggests there are no sorting effects. Similarly, we do not find evidence of students' sorting. Students that were enrolled into JEC schools the year before the policy change took place are not statistically different from those that moved to JEC schools.

\section{Child non-cognitive skills}

We also look at the potential impact of JEC on socio-emotional and technical skills. The former might improve due to the increase in the number of psychologists available at the school (that are meant to interact directly with students), and the latter by having access to more IT resources (according to information collected by us from Ministry of Education, computer labs at JEC schools were used to teach students how to use software such as Microsoft Word and Microsoft Excel). For functional skills, we look at two types of outcomes. First, we look at child self-report of her abilities speaking English (63\% of children report that they speak English "well" or "a little bit"). Second, we use three scales designed by the YLS to measure digital skills (Cueto et al., 2018). The first scale measures access to digital devices (computers, laptops, tablets, smartphones) and to the Internet ( $72 \%$ of the sample reports having used digital devices recently). The second and third scales, which are only applied if the child has access to digital devices and to the Internet (respectively), measure the skills that child has using computer and browsing the Internet. In all cases, information is self-reported. 
For educational aspirations we consider two outcomes: whether or not the child aspires to complete higher education (including any post-secondary education), and whether the child aspires to go to university. For socio-emotional competencies (Yorke and Ogando Portela, 2018), we consider the notions of self-esteem and self-efficacy, both of which have been found to matter to predict life outcomes, including access to higher education, risk behaviours, and teenage pregnancy (Sánchez and Singh, 2018; Favara and Sánchez, 2017; Favara, et al., 2020). Indeed, our analysis uncovers a positive impact of the program on socio-emotional skills and technical skills, summarized in our constructed indexes with effects by 0.17 and $0.16 \mathrm{SD}$, respectively (Table 7). The former is explained by an increase in aspirations, self-efficacy, and self-esteem, whereas the latter is driven by an increase in access to digital media and self-reported knowledge of English.

\section{Other channels}

Finally, we use data from ECE-S to explore whether JEC led to changes in parental involvement. ${ }^{19}$ Figure A5 (Appendix) displays the reduced-form relation for all five outcomes against the number of sections. This visual inspection does not suggest a change in parental behavior. Table A10 (Appendix) indicates a zero effect from JEC, using the 2SLS estimator, on whether students talk to their parents about homework (column 1), whether parents explain topics (column 3) and if parents care about the students' grade (column 4). There is a slight increase in the probability that parents help with homework (column 2 ) that is significant at $p<0.05$, but also a marginal decline in the probability that parents recommend books to their children (column 5). If anything, this negative effect is consistent with the weaker impact of JEC on reading test scores.

Next, we investigate students' own perception about reading and math separately in response to JEC. The reduced-form graphs tend to suggest an overall lack of behavioral change (Figure A6, Appendix) but negative for some reading outcomes (Panel A) and less so for math (Panel B). The 2SLS estimates reported in Table A11 (Appendix) confirm that, if anything, the negative responses tend to be centered on reading (Panel A). Students in JEC schools declare that they are less likely to understand hard topics (column 3), feel less confident on tests (column 4) and on passing the course (column 7) as well as less likely to seeing themselves as good at solving reading-related problems (column 8). In math, Panel B, such negative effects are not found.

\footnotetext{
${ }^{19}$ Each question had a multiple-choice response (i.e., never, rarely, very often, always). Answers selecting "very often" or "always" were coded as one and zero otherwise.
} 
Students, however, are less likely to help their peers, suggestive a more competitive attitude. Again, the differential impact of JEC on math and reading could be explained by how the reform has altered the students' own perceptions as we observe that students in reading are more likely to feel marginalized and to have a lower self-perception.

This analysis is complemented with the students' report about their teachers and their courses. An important drawback is the fact that the survey framed this set of questions by asking students to combine their view of the math and reading courses. The reduced-form graphs, Figure A7 (Appendix), suggest very little change around the threshold and it is confirmed with the 2SLS estimates reported in Table A12. Given the combination of subjects it is impossible to conclude whether there is no change in teachers at all or if, as before, the negative behavioral responses are more likely to be present in reading than in math, leading to null net effect.

\section{Conclusions}

This paper evaluates a policy that seeks to improve education quality and learning outcomes in a developing country by increasing pedagogical hours, whilst also adding accompanying investments in school inputs. The JEC program expanded the school day from 35 to 45 pedagogical hours a week in Peruvian public schools. We exploit an arbitrary rule used in the selection of schools into the program to identify the effect on math, reading and other outcomes.

We find that the JEC program leads to more learning as measured by standardized test scores. The effects are robust and larger for math relative to the literature. They are somewhat smaller and slightly less robust, but positive, for reading. Exploring several other datasets allows us to investigate key mechanisms of impact including school resources, teacher attitudes and time use, and pupil behavioral responses. We find that students do not substitute their time from

studying but rather work fewer hours outside of school and decrease their leisure time. We also see improvements in student access to digital technology, increased technical and socioemotional skills, and greater support to teachers to improve their pedagogical practice.

Overall, our results suggest that, with targeted investment, it is possible to improve the quality of public sector education. 


\section{References}

Agüero, J. M., and Beleche, T. (2013). Test-Mex: Estimating the effects of school year length on student performance in Mexico. Journal of Development Economics, 103, 353-361.

Aguirre, J. (2020). How can progressive vouchers help the poor benefit from school choice? evidence from the Chilean voucher system. Journal of Human Resources, online before print: 0318-9386R2.

Angrist, J., Bettinger, E., Bloom, E., King, E. and Kremer, M., 2002. Vouchers for private schooling in Colombia: Evidence from a randomized natural experiment. The American Economic Review, 92(5), pp.1535-1558.

Angrist, J., Bettinger, E., \& Kremer, M. (2006). Long-term educational consequences of secondary school vouchers: Evidence from administrative records in Colombia. The American Economic Review, 96(3), 847-862.

Angrist, J. D., Pathak, P. A., \& Walters, C. R. (2013). Explaining charter school effectiveness. American Economic Journal: Applied Economics, 5(4), 1-27.

Barrera-Osorio, F., De Galbert, P., Habyarimana, J. \& Sabarwal. (2020). The Impact of Public-Private Partnerships on Private School Performance: Evidence from a Randomized Controlled Trial in Uganda. Economic Development and Cultural Change, 429-469.

Bellei, C. (2009). Does lengthening the school day increase students' academic achievement? Results from a natural experiment in Chile. Economics of Education Review, 28(5), 629-640.

Ben-Porath, Y. (1967). The production of human capital and the life cycle of earnings. The Journal of Political Economy, 352-365.

Cabrera-Hernández, F. (2020). Does Lengthening the School Day Increase School ValueAdded? Evidence from a Mid-Income Country. The Journal of Development Studies, 56(2), 314-335. DOI: 10.1080/00220388.2018.1563680 
Card, D., and Krueger, A. B. (1992). Does School Quality Matter? Returns to Education and the Characteristics of Public Schools in the United States. The Journal of Political Economy, 100(1), 1-40.

Cattaneo, M. D., Idrobo, N., \& Titiunik, R. (2018). A Practical Introduction to Regression Discontinuity Designs: Volume II. Cambridge Elements: Quantitative and Computational Methods for Social Science, II, 113.

Cerdan-Infantes, P., and Vermeersch, C. (2007). More Time Is Better: An Evaluation of the Full-Time School Program in Uruguay. Impact Evaluation Series.

Cueto, S., León, J., Guerrero, G. \& Muñoz, I. (2009). Psychometric characteristics of cognitive development and achievement instruments in Round 2 of Young Lives. Young Lives Technical Note 15.

Cueto, S. \& León, J. (2012). Psychometric Characteristics of Cognitive Development and Achievement Instruments in Round 3 of Young Lives. Young Lives Technical Note 25.

Cueto, S., Felipe, C. \& León, J. (2018). Digital Access, Use and Skills Across Four Countries: Construction of Scales and Preliminary Results from the Young Lives Round 5 Survey. Young Lives Technical Note 46.

Das, J., Dercon, S., Habyarimana, J., Krishnan, P., Muralidharan, K., \& Sundararaman, V. (2013). School inputs, household substitution, and test scores. American Economic Journal: Applied Economics, 5(2), 29-57.

Dobbie, W., \& Fryer Jr, R. G. (2013). Getting beneath the veil of effective schools: Evidence from New York City. American Economic Journal: Applied Economics, 5(4), 28-60.

Dunn, L., Padilla, E., Lugo, D., \& Dunn, L. (1986). Test de Vocabulario en Imagenes Peabody-Adaptacion Hispanoamericana [Peabody Picture Vocabulary Test-Latin American adaptation]. Circle Pines, MN: American Guidance Service.

Favara, M. \& Sánchez, A. (2017). Psychosocial competencies and risky behaviours in Peru. IZA Journal of Labor \& Development, 6(3), 1-40. 
Favara, M., Lavado, P. \& Sánchez, A. (2020). Understanding teenage fertility in Peru: An analysis using longitudinal data. Review of Development Economics, 24(4), 1217-1236.

Fryer Jr, R. G. (2014). Injecting charter school best practices into traditional public schools: Evidence from field experiments. The Quarterly Journal of Economics, 129(3), 13551407.

Glewwe, P. and Muralidharan, K. (2016) Improving Education Outcomes in Developing Countries: Evidence, Knowledge Gaps, and Policy Implications. Handbook of the Economics of Education 5, pp. 653-743.

Hincapie, D. (2016). Do longer school days improve student achievement? Evidence from Colombia. IDB Working Paper Series No. IDB-WP-679.

Holland, P., Evans, D. and Alfaro, P. (2014) Extending the School Day in Latin America and the Caribbean: Evidence, Experience, Challenges. World Bank Policy Research Working Paper, 7309.

Jackson, C. K. (2020). Does school spending matter? The new literature on an old question. In L. Tach, R. Dunifon, \& D. L. Miller (Eds.), Confronting inequality: How policies and practices shape children's opportunities (p. 165-186). American Psychological Association.

Kremer, M., Brannen, C. and Glennerster, R. (2013). The Challenge of Education and Learning in the Developing World. Science, 340(6130), pp.297-300.

Lavy, V. (2015). Do differences in schools' instruction time explain international achievement gaps? Evidence from developed and developing countries. The Economic Journal, 125(588), pp. F397-F424.

Lee, D.S. and Card, D. (2008). Regression discontinuity inference with specification error. Journal of Econometrics, 142(2), pp.655-674.

Lee, J. W., and Barro, R. J. (2001). Schooling quality in a cross-section of countries. Economica, 68(272), 465-488. 
Levin, H. M., \& Tsang, M. C. (1987). The economics of student time. Economics of education review, 6(4), 357-364.

Manacorda, M., 2012. The cost of grade retention. Review of Economics and Statistics, 94(2), pp.596-606.

Mbiti, I., Muralidharan, K., Romero, M., Schipper, Y., Manda, C., \& Rajani, R. (2019). Inputs, incentives, and complementarities in education: Experimental evidence from Tanzania. The Quarterly Journal of Economics, 134(3), 1627-1673.

McMullen, S.C. and Rouse, K.E., 2012. The impact of year-round schooling on academic achievement: Evidence from mandatory school calendar conversions. American Economic Journal: Economic Policy, 4(4), pp.230-252.

MINEDU (2014) "Modelo de servicio educativo: jornada escolar completa para las instituciones educativas públicas del nivel de educación secundaria”, Setiembre.

Muralidharan, K., Singh, A., \& Ganimian, A. J. (2019). Disrupting education? Experimental evidence on technology-aided instruction in India. American Economic Review, 109(4), 1426-60.

Muralidharan, K. and Sundararaman, V. (2015). The aggregate effect of school choice: Evidence from a two-stage experiment in India. The Quarterly Journal of Economics, 130(3):1011-1066.

Orkin, K. (2013). The Effect of Lengthening the School Day on Children's Achievement in Ethiopia. Young Lives Working Paper 119.

Padilla-Romo, Maria. (2017) “The Short and Long Run Effects of Full-Time Schools on Academic Performance” Mimeo. Texas A\&M University.

Parinduri, R.A., 2014. Do children spend too much time in schools? Evidence from a longer school year in Indonesia. Economics of Education Review, 41, pp.89-104.

Pires, T., and Urzúa, S. (2015). Longer School Days, Better Outcomes? Manuscript, University of North Carolina. 
Pop-Eleches, C., and Urquiola, M. (2013). Going to a Better School: Effects and Behavioral Responses. The American Economic Review, 103(4), 1289-1324.

Rivkin, S. G., and Schiman, J. C. (2015). Instruction time, classroom quality, and academic achievement. The Economic Journal, 125(588), F425-F448.

Romero, M., Sandefur, J., \& Sandholtz, W. A. (2020). Outsourcing education: Experimental evidence from Liberia. American Economic Review, 110(2), 364-400.

Sánchez, A. \& Singh, A. (2018). Accessing higher education in developing countries: Panel data analysis from India, Peru, and Vietnam. World Development, 109, 261-278.

Tafreschi, D. and Thiemann, P., 2016. Doing it twice, getting it right? The effects of grade retention and course repetition in higher education. Economics of Education Review, 55, pp.198-219.

Todd, P. E., and Wolpin, K. I. (2003). On the specification and estimation of the production function for cognitive achievement*. The Economic Journal, 113(485), F3-F33.

UNICEF. (2011). The State of the World's Children 2011 Adolescence-An Age of Opportunity. Unicef.

Wössmann, L. (2003). Schooling resources, educational institutions and student performance: the international evidence. Oxford bulletin of economics and statistics, 65(2), 117-170.

Yorke, L. \& Ogando Portela, M.J. (2018). Psychosocial Scales in the Young Lives Round 4 Survey Selection, Adaptation and Validation. Young Lives Technical Note 45. 


\section{Tables and Figures}

Table 1. First stage: Participation in JEC

\begin{tabular}{|c|c|c|c|c|c|}
\hline \multirow{3}{*}{ Sample: } & \multicolumn{5}{|c|}{ Dependent variable: School participates in JEC $(=1)$} \\
\hline & All & All & Urban & Urban & 7 and 8 \\
\hline & (1) & (2) & (3) & (4) & (5) \\
\hline Section $\geq 8$ & $\begin{array}{c}0.479 * * * \\
{[0.020]}\end{array}$ & $\begin{array}{c}0.461 * * * \\
{[0.027]}\end{array}$ & $\begin{array}{c}0.491 * * * \\
{[0.025]}\end{array}$ & $\begin{array}{c}0.446^{* * *} \\
{[0.039]}\end{array}$ & $\begin{array}{c}0.518^{* * * *} \\
{[0.048]}\end{array}$ \\
\hline Spline & Linear & Quadratic & Linear & Quadratic & \\
\hline $\mathrm{N}$ & 8473 & 8473 & 4419 & 4419 & 571 \\
\hline $\mathrm{R}^{2}$ & 0.438 & 0.441 & 0.444 & 0.448 & 0.458 \\
\hline
\end{tabular}


Table 2. Impact of JEC on academic achievement

\begin{tabular}{lcccc}
\hline Sample: & All & Urban & $\begin{array}{c}\text { Morning } \\
\text { shift }\end{array}$ & $\begin{array}{c}\text { Urban and } \\
\text { morning shift }\end{array}$ \\
& $(1)$ & $(2)$ & $(3)$ & $(4)$ \\
\hline
\end{tabular}

Panel A. Dependent variable: Reading test scores

$\begin{array}{lcccc}\text { JEC } & 0.149 * * * & 0.240^{* * *} & 0.096^{* *} & 0.185 * * * \\ & {[0.048]} & {[0.064]} & {[0.041]} & {[0.054]} \\ & \{0.044\} & \{0.049\} & \{0.038\} & \{0.048\} \\ \mathrm{N} & 360,154 & 296,063 & 189,630 & 131,337 \\ \text { Adj-R2 } & 0.262 & 0.191 & 0.315 & 0.260 \\ \text { F-stat } & 395.9 & 213.5 & 502.6 & 316.2\end{array}$

Panel B. Dependent variable: Reading Pr(grade level)

$\begin{array}{lcccc}\text { JEC } & 0.043 * * * & 0.061 * * * & 0.029 * * * & 0.046 * * * \\ & {[0.009]} & {[0.013]} & {[0.008]} & {[0.013]} \\ & \{0.009\} & \{0.011\} & \{0.007\} & \{0.010\} \\ \mathrm{N} & 360,154 & 296,063 & 189,630 & 131,337 \\ \text { Adj-R2 } & 0.083 & 0.072 & 0.123 & 0.111 \\ \text { F-stat } & 395.9 & 213.5 & 502.6 & 316.2\end{array}$

Panel C. Dependent variable: Math test scores

$\begin{array}{lcccc}\text { JEC } & 0.243 * * * & 0.307 * * * & 0.179 * * * & 0.233 * * * \\ & {[0.053]} & {[0.073]} & {[0.046]} & {[0.068]} \\ & \{0.045\} & \{0.046\} & \{0.034\} & \{0.040\} \\ \mathrm{N} & 360,076 & 295,986 & 189,609 & 131,316 \\ \text { Adj-R2 } & 0.197 & 0.159 & 0.240 & 0.206 \\ \text { F-stat } & 396.2 & 213.8 & 502.3 & 315.9\end{array}$

Panel D. Dependent variable: Math Pr(grade level)

$\begin{array}{lcccc}\text { JEC } & 0.053 * * * & 0.072 * * * & 0.042 * * * & 0.058 * * * \\ & {[0.011]} & {[0.015]} & {[0.010]} & {[0.014]} \\ & \{0.009\} & \{0.012\} & \{0.007\} & \{0.009\} \\ \mathrm{N} & 360,076 & 295,986 & 189,609 & 131,316 \\ \text { Adj-R2 } & 0.055 & 0.051 & 0.074 & 0.072 \\ \text { F-stat } & 396.2 & 213.8 & 502.3 & 315.9\end{array}$

Note: Robust standard clustered at the school district are shown in brackets and by section in \{\} . Each column reports 2SLS using the discontinuity at 8 sections and with linear splines. All regressions include controls for age and gender of the student, as well as fixed effects for their mothers' educational attainment and language spoken together with fixed effects for urban/rural, shift and school district. F-stat refers to the instrument in the first stage. $* \mathrm{p}<0.10, * * \mathrm{p}<0.05$, $* * * \mathrm{p}<0.01$. 
Table 3. Robustness: First stage and reduced form using local randomization

\begin{tabular}{lccccc}
\hline & First stage & \multicolumn{4}{c}{ Reduced-form } \\
\cline { 3 - 6 } & & \multicolumn{3}{c}{ Reading } & \multicolumn{3}{c}{ Math } \\
& JEC & Z-score & Grade-level & Z-score & Grade-level \\
& $(1)$ & $(2)$ & $(3)$ & $(4)$ & $(5)$ \\
\hline & & & & 0.095 & 0.020 \\
1(S>=8) & 0.494 & 0.037 & 0.007 & {$[0.000]$} & {$[0.000]$} \\
P-values & {$[0.000]$} & {$[0.010]$} & {$[0.112]$} & & \\
Sample size & & & & 6625 & 6625 \\
S=7 & 6631 & 6626 & 6626 & 6869 & 6869 \\
S=8 & 6875 & 6871 & 6871 & & \\
\hline
\end{tabular}

Note: P-values for local randomization shown in brackets. Each column represents a separate regression. Sample is restricted to public urban schools with seven or eight sections. 
Table 4: Impact of JEC on time use of students (in hours)

\begin{tabular}{lllll}
\hline & \multicolumn{1}{c}{ Coef } & s.e. & $\begin{array}{c}\text { Adjusted } \\
\text { p-value }\end{array}$ & $\mathrm{n}$ \\
\hline Student time use in a typical & & & & \\
school day & & & & \\
$\quad$ Sleeping & $-0.219^{*}$ & $(0.116)$ & 0.105 & 1,174 \\
$\quad$ Caring for household members & -0.083 & $(0.106)$ & 0.553 & 1,174 \\
$\quad$ Household chores & $-0.393^{* * *}$ & $(0.087)$ & 0.000 & 1,174 \\
Domestic tasks & $-0.514^{* * *}$ & $(0.131)$ & 0.000 & 1,174 \\
Paid activity & 0.057 & $(0.097)$ & 0.668 & 1,174 \\
In school & $2.145^{* * *}$ & $(0.136)$ & 0.000 & 1,174 \\
$\quad$ Studying outside school & -0.085 & $(0.092)$ & 0.476 & 1,174 \\
$\quad$ Leisure activities & $-0.728^{* * *}$ & $(0.151)$ & 0.000 & 1,174 \\
\hline
\end{tabular}

Notes: Young Lives data. Robust standard errors clustered at the community level in brackets. Sample is restricted to children attending public schools. Each column reports 2SLS estimates using the discontinuity at eight sections. All regressions include linear splines, controls for child's age, sex and language, mother's language plus fixed effects by community and shift. $* \mathrm{p}<0.10,{ }^{* *} \mathrm{p}<0.05, * * * \mathrm{p}<0.01$. 
Table 5: Impact of JEC on school infrastructure, staff resources, and pedagogy

\begin{tabular}{|c|c|c|c|c|}
\hline & Coef & s.e. & $\begin{array}{l}\text { Adjusted } \\
\text { p-value }\end{array}$ & $\mathrm{n}$ \\
\hline $\begin{array}{l}\text { Panel A: School access to IT } \\
\text { (index) }\end{array}$ & $0.807 * * *$ & $(0.131)$ & & 6,226 \\
\hline 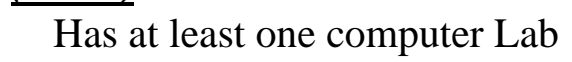 & $-0.084 * *$ & $(0.038)$ & 0.033 & 6,226 \\
\hline $\begin{array}{l}\text { Number of classrooms with } \\
\text { computer }\end{array}$ & $0.557 *$ & $(0.302)$ & 0.078 & 6,226 \\
\hline $\begin{array}{l}\text { Number of classrooms with } \\
\text { laptop }\end{array}$ & $3.722 * * *$ & $(0.710)$ & 0.000 & 6,226 \\
\hline $\begin{array}{l}\text { Technical equipment receives } \\
\text { maintenance }\end{array}$ & $0.434 * * *$ & $(0.034)$ & 0.000 & 6,141 \\
\hline Kit Robotica & -0.017 & $(0.035)$ & 0.657 & 6,141 \\
\hline Panel B: School staff (index) & $1.691 * * *$ & $(0.161)$ & & 6,226 \\
\hline Complete teaching staff & $-0.091 *$ & $(0.039)$ & 0.023 & 6,226 \\
\hline Number of se & $1.379 * * *$ & $(0.094)$ & 0.000 & 6,226 \\
\hline Number of maintenance staff & 0.109 & $(0.150)$ & 0.499 & 6,226 \\
\hline $\begin{array}{l}\text { Panel C: School pedagogical } \\
\text { support (index) }\end{array}$ & $5.109 * * *$ & $(0.148)$ & & 6,226 \\
\hline School has a psychologist & $0.807 * * *$ & $(0.025)$ & 0.000 & 6,226 \\
\hline $\begin{array}{l}\text { Schools receives program } \\
\text { "Acompañamiento Pedagogico" }\end{array}$ & $0.732 * * *$ & $(0.034)$ & 0.000 & 6,226 \\
\hline $\begin{array}{l}\text { Teachers provide support to } \\
\text { parents }\end{array}$ & $0.296 * * *$ & $(0.031)$ & 0.000 & 6,226 \\
\hline
\end{tabular}

Note: SEMAFORO data. Sample includes all public schools in the sample. Robust standard errors clustered at the school district level in brackets. Sample is restricted to children attending public schools. Each column reports 2SLS estimates using the discontinuity at eight sections. All regressions include linear splines, an urban dummy, and school district fixed effects. $* \mathrm{p}<0.10, * * \mathrm{p}<0.05, * * * \mathrm{p}<0.01$ 
Table 6: Impact of JEC on teacher characteristics, training, and behaviors

\begin{tabular}{|c|c|c|c|c|}
\hline & Coef & s.e. & $\begin{array}{l}\text { Adjusted } \\
\text { p-value }\end{array}$ & $\mathrm{n}$ \\
\hline \multicolumn{5}{|l|}{ Panel A: Teacher's time use } \\
\hline $\begin{array}{l}\text { Teacher time dedicated to school activities } \\
\text { (weekdays) index }\end{array}$ & -0.127 & $(0.128)$ & 0.363 & 2,825 \\
\hline $\begin{array}{l}\text { Teacher time dedicated to school activities } \\
\text { (weekend) index }\end{array}$ & 0.051 & $(0.097)$ & 0.639 & 2,825 \\
\hline $\begin{array}{l}\text { Teacher time dedicated to activities outside school } \\
\text { (weekdays) index }\end{array}$ & 0.055 & $(0.116)$ & 0.673 & 2,825 \\
\hline $\begin{array}{l}\text { Teacher time dedicated to activities outside school } \\
\text { (weekend) index }\end{array}$ & 0.084 & $(0.083)$ & 0.354 & 2,825 \\
\hline Spent time in other income activities & $0.148 * *$ & $(0.071)$ & 0.048 & 2,825 \\
\hline Other income activity: work in other school (public) & $0.027 *$ & $(0.014)$ & 0.076 & 2,825 \\
\hline Other income activity: work in other school (private) & $0.066 * *$ & $(0.031)$ & 0.046 & 2,825 \\
\hline Other income activity: own business & 0.068 & $(0.051)$ & 0.217 & 2,825 \\
\hline Teach in more than 1 high-school & 0.011 & $(0.049)$ & 0.840 & 2,801 \\
\hline Panel B: Teacher attitudes and satisfaction (index) & -0.098 & $(0.087)$ & & 2,825 \\
\hline Total score on items indicating teacher's satisfaction & -0.279 & $(0.595)$ & 0.679 & 2,825 \\
\hline Teacher's satisfaction with his/her job & 0.018 & $(0.101)$ & 0.877 & 2,824 \\
\hline Positive perception of teacher profession & -0.019 & $(0.069)$ & 0.811 & 2,825 \\
\hline Would choose again to be a teacher & $-0.155 * *$ & $(0.063)$ & 0.019 & 2,825 \\
\hline Teacher is happy with current work & -0.009 & $(0.050)$ & 0.878 & 2,823 \\
\hline Decided to be a teacher by choice & -0.037 & $(0.057)$ & 0.565 & 2,817 \\
\hline Panel C: Teacher training \& pedagogy (index) & $0.271 * * *$ & $(0.083)$ & & 2,825 \\
\hline Number of subjects currently teaching & $-0.556 * * *$ & $(0.123)$ & 0.000 & 2,805 \\
\hline Developed innovative practices & -0.059 & $(0.074)$ & 0.473 & 2,825 \\
\hline Top quintile in good teaching practice score & 0.043 & $(0.061)$ & 0.526 & 2,817 \\
\hline Received "Acompañamiento pedagógico" & $0.248 * * *$ & $(0.074)$ & 0.001 & 2,825 \\
\hline Received ICT training & 0.110 & $(0.074)$ & 0.169 & 2,824 \\
\hline $\begin{array}{l}\text { Panel D: Teacher predetermined characteristics } \\
\text { (index)* }\end{array}$ & 0.028 & $(0.066)$ & & 2,825 \\
\hline Age & -0.615 & $(1.312)$ & 0.678 & 2,819 \\
\hline Female & 0.074 & $(0.081)$ & 0.406 & 2,825 \\
\hline Completed studies at university & 0.089 & $(0.081)$ & 0.313 & 2,621 \\
\hline Completed studies at private institution & -0.035 & $(0.058)$ & 0.592 & 2,617 \\
\hline Completed any post-graduate studies & 0.020 & $(0.061)$ & 0.779 & 2,825 \\
\hline Number of years teaching in current high school & 1.939 & $(2.175)$ & 0.419 & 1,770 \\
\hline Top Levels at Escala Magisterial & -0.081 & $(0.050)$ & 0.134 & 2,820 \\
\hline Teacher has a permanent contract ("Nombrado/a") & -0.083 & $(0.079)$ & 0.334 & 2,825 \\
\hline
\end{tabular}

Note: ENDO data. Sample includes all public schools in the sample. 
Table 7. Impact of JEC on non-cognitive and technical skills

\begin{tabular}{lcccc}
\hline & & \multicolumn{3}{c}{ Adjusted } \\
& Coef & s.e. & p-value & $\mathrm{n}$ \\
\hline Student socio-emotional skills & $\mathbf{0 . 1 7 2 * *}$ & $\mathbf{( 0 . 0 7 9 )}$ & & 1,174 \\
\hline (index) & 0.019 & $(0.019)$ & 0.455 & 1,174 \\
\multicolumn{1}{c}{ Aspirations for higher education } & $0.065^{* *}$ & $(0.026)$ & 0.024 & 1,174 \\
Aspirations for university & $0.148^{* *}$ & $(0.070)$ & 0.066 & 1,174 \\
Self-efficacy & $0.142 * *$ & $(0.066)$ & 0.059 & 1,174 \\
Self-esteem & 0.088 & $(0.105)$ & 0.517 & 1,174 \\
Pride & 0.102 & $(0.094)$ & 0.395 & 1,174 \\
Agency & & & & \\
& $\mathbf{0 . 1 6 4 *}$ & $\mathbf{( 0 . 0 9 7 )}$ & & 1,174 \\
Student technical skills (index) & $0.289 * * *$ & $(0.050)$ & 0.000 & 1,174 \\
$\quad$ Speak English & $0.269 * * *$ & $(0.066)$ & 0.000 & 1,174 \\
Access Digital & -0.057 & $(0.061)$ & 0.472 & 1,174 \\
Computer skills & -0.070 & $(0.055)$ & 0.302 & 1,174 \\
Internet skills & & & & \\
& & &
\end{tabular}

Notes: Young Lives data. Robust standard errors clustered at the community level in brackets. Sample is restricted to children attending public schools. Each column reports 2SLS estimates using the discontinuity at eight sections. All regressions include linear splines, controls for child's age, sex and language, mother's language plus fixed effects by community and shift. $* \mathrm{p}<0.10, * * \mathrm{p}<0.05, * * * \mathrm{p}<0.01$. 
Figure 1. First Stage: participation in JEC by number of sections

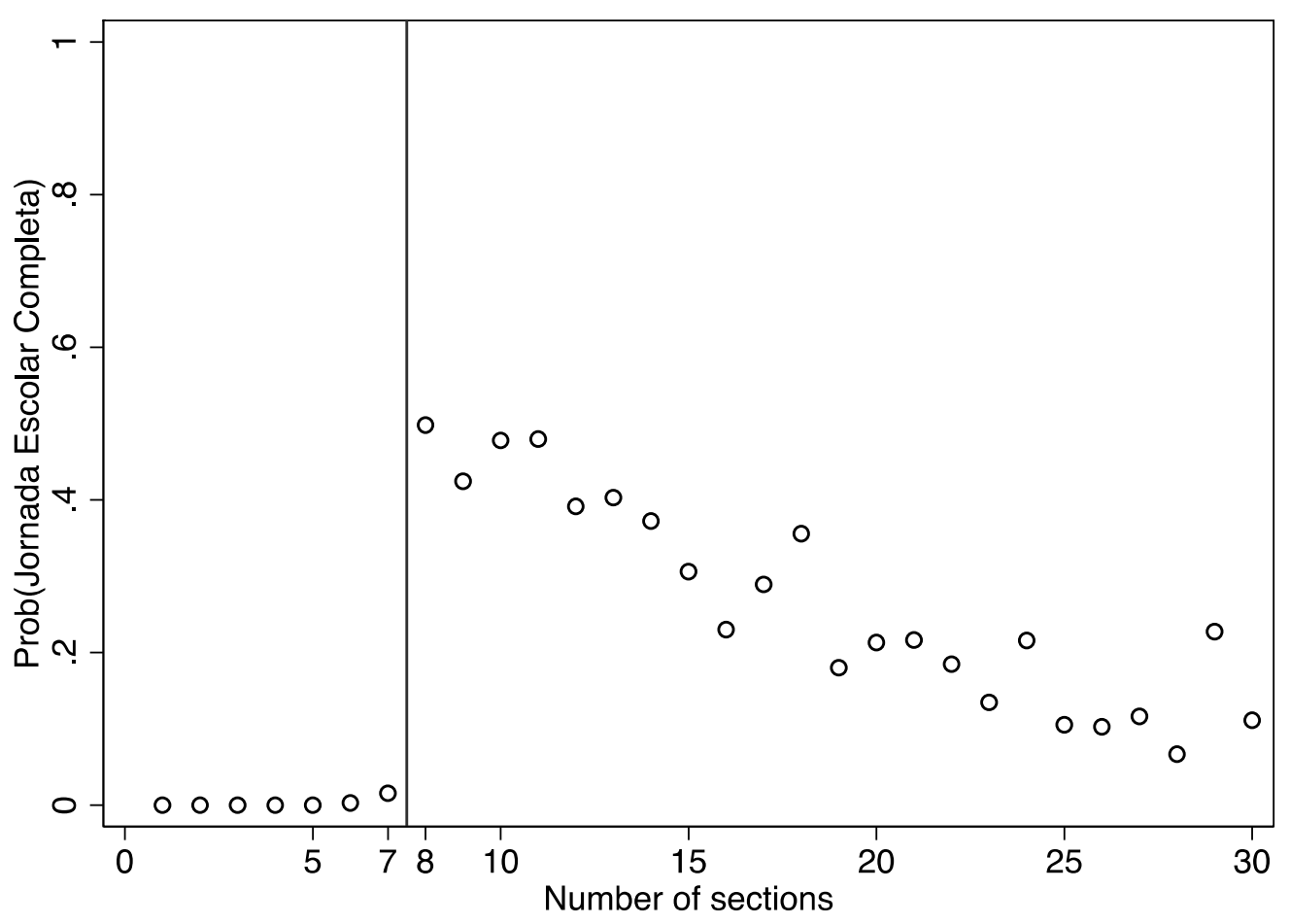

Note: Each circle represents the share of schools that belong to JEC by their number of sections. Sample includes all public high schools. Source: Author's calculation based on 2013 Censo Escolar. 


\section{Figure 2. Smoothness tests at the school level}

A. Start, end and length of school day

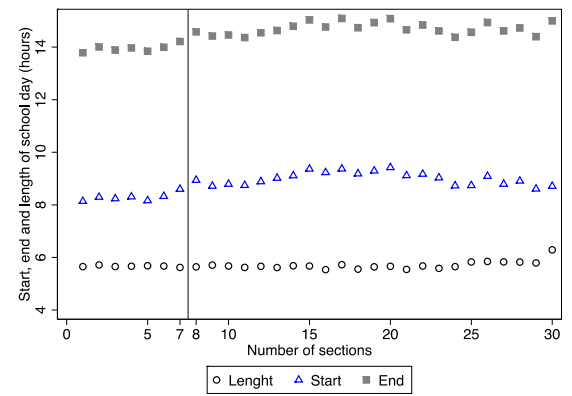

D. Passing rates

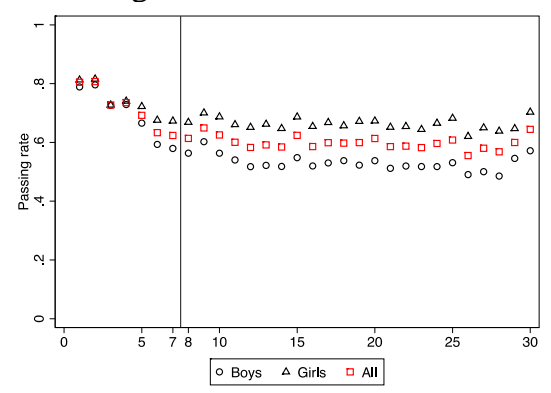

B. Access to welfare programs

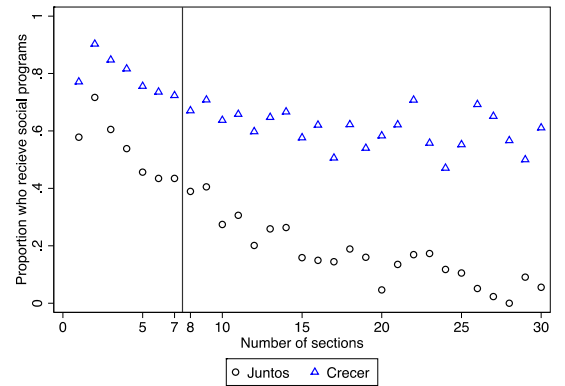

E. Urban location

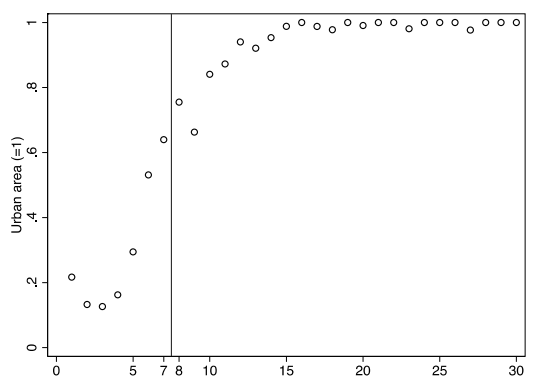

G. Indigenous language

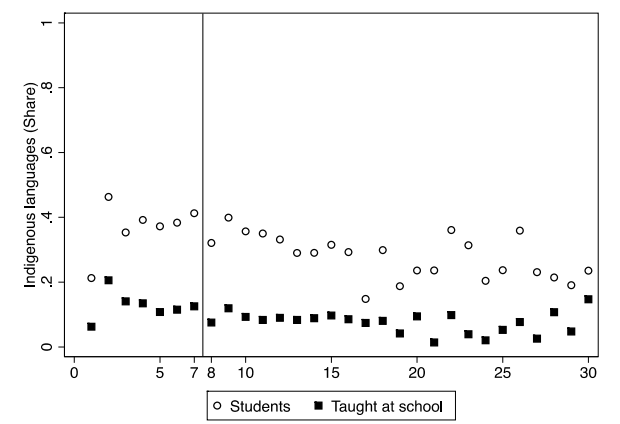

C. Enrollment

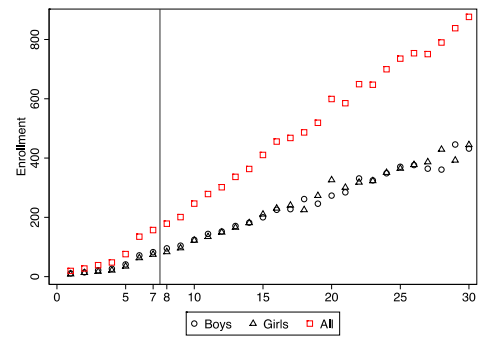

F. Only morning-shift

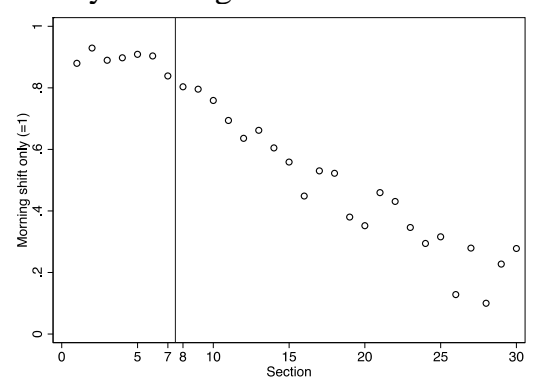

Note: Each symbol represents the sample average by section. Sample includes all public schools. Data source: 2013 Censo Escolar. 
Figure 3: Smoothness tests at the student level
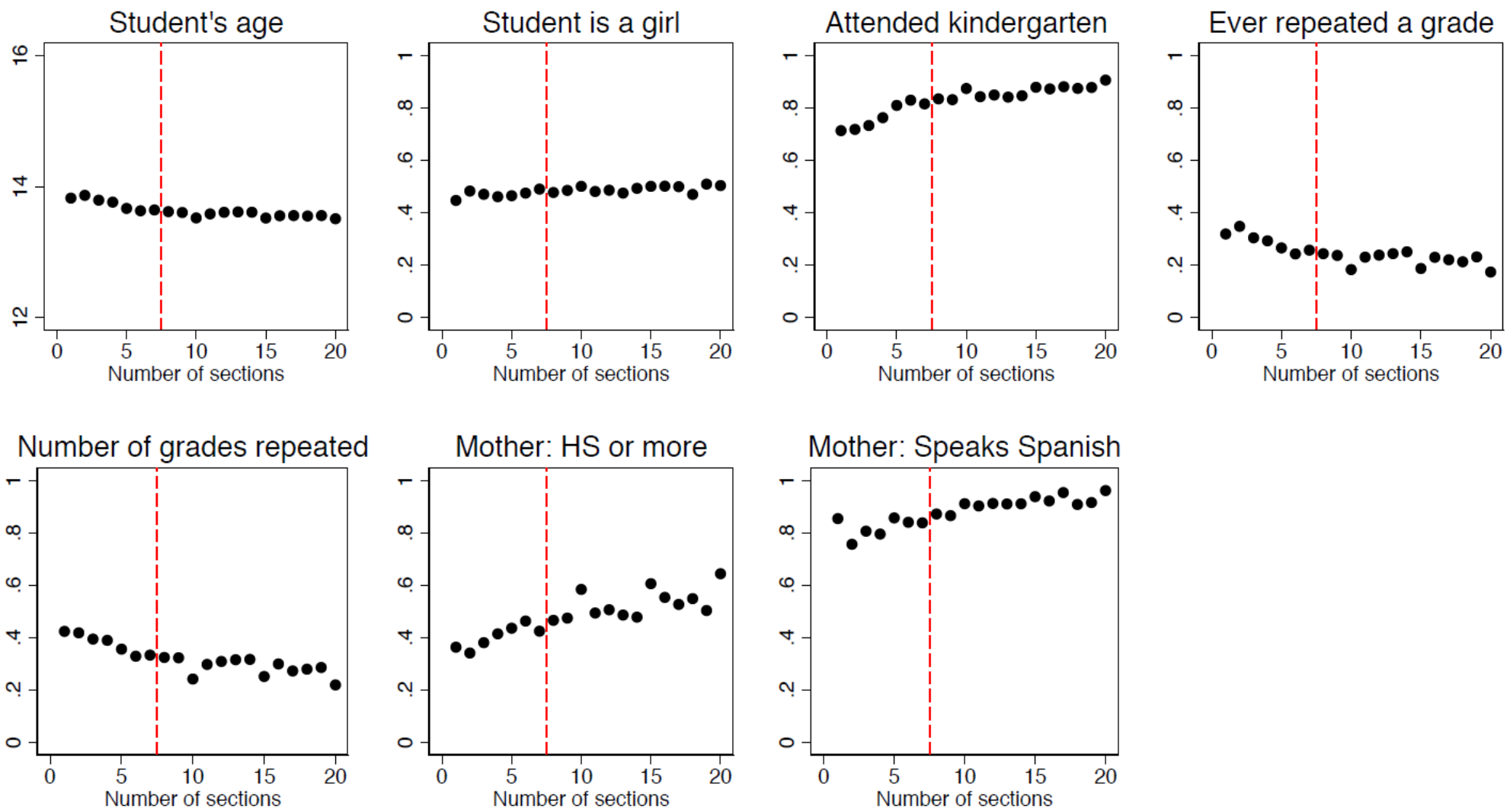

Data source: 2013 Censo Escolar. 


\section{Figure 4. Impact of JEC on test scores (reduced form)}
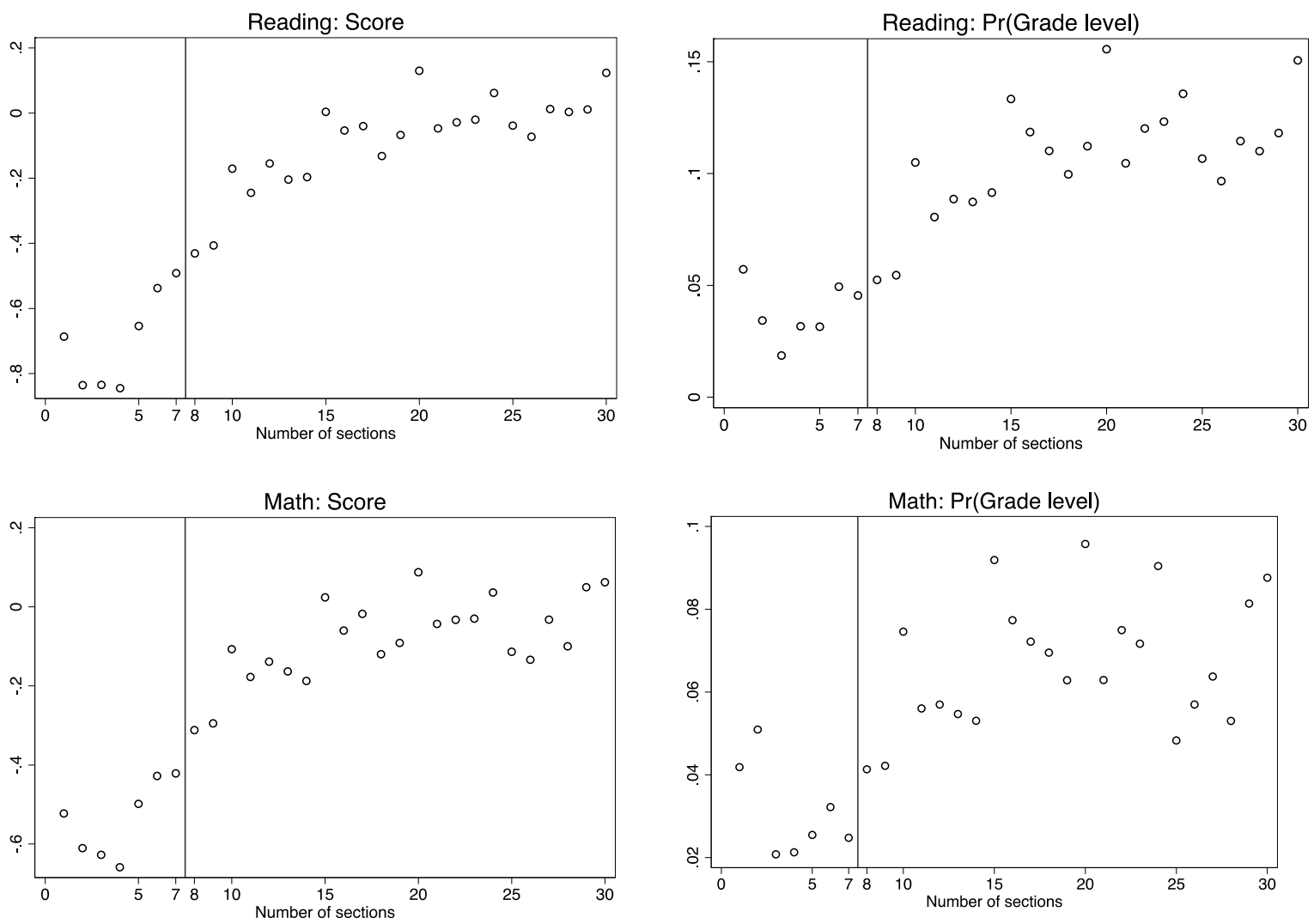

Note: Each symbol represents the sample average by section. Sample includes all public schools.

Data source: 2015 ECE-S. 
Appendix

Tables and Figures

Table A1: Distribution of hours by type of public high school

\begin{tabular}{lcc}
\hline Subject & Simple & JEC \\
\hline Mathematics & 4 & 6 \\
Reading & 4 & 5 \\
English & 2 & 5 \\
Science & 3 & 5 \\
History & 3 & 3 \\
Work education & 2 & 3 \\
Civics & 2 & 3 \\
Person, family \& community & 2 & 2 \\
Physical education & 2 & 2 \\
Art & 2 & 2 \\
Religion & 2 & 2 \\
Tutoring & 1 & 2 \\
Free & 6 & 5 \\
Total & 35 & 45 \\
\hline Note: A pedaggin
\end{tabular}

Note: A pedagogical hours is 45 minutes long. Source: MINEDU 


\section{Table A2: Selection process: JEC high schools}

1. Rules for selection chosen:

- Public high schools

- Schools with morning shift only

- Eight or more 'Sections'

- School facilities used only in the morning

- Schools with sufficient space to install new classrooms.

These 5 criteria yielded $\underline{1,360}$ high schools

2. 52 "emblematic" high schools were added $(\underline{1,412 \text { schools })}$

3. List was sent to local coordinators for validation. New list with $\underline{1,343}$ schools. These schools now needed to provide additional information.

4. Based on this information and depending on the date of arrival, $\underline{1,000}$ public schools were selected for JEC.

5. In September of 2014 JEC is created (RM N 451-2014-MINEDU).

6. On February 102015 the list was modified replacing six schools (RM No 062-2015-MINEDU).

This was the final list of schools included in JEC in 2015.

Source: MINEDU (2015) “Proceso de selección la JEC 2015” and “Criterios de Selección IIEE 2015 a 2017 ”. Note that a section is equivalent to a homeroom in the US system, and a form class in the UK system. 
Table A3: Summary statistics: Standardized test (ECE-S)

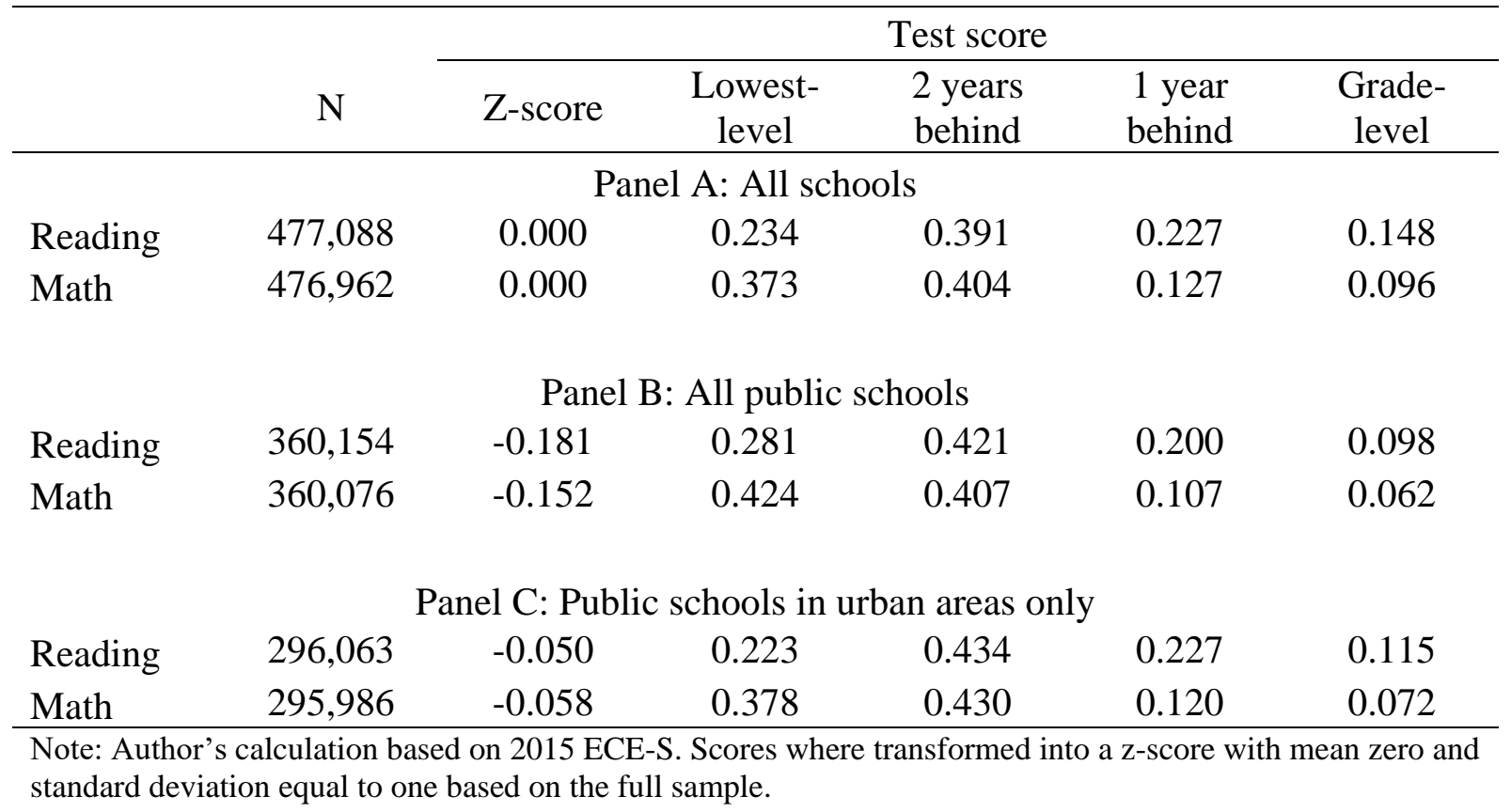


Table A4: Smoothness test at school level

\begin{tabular}{|c|c|c|c|c|c|c|c|c|c|}
\hline & \multicolumn{9}{|c|}{ Dependent variable } \\
\hline & \multicolumn{2}{|c|}{$\begin{array}{c}\text { School/District } \\
\text { receives welfare } \\
\text { program }\end{array}$} & \multirow{2}{*}{$\begin{array}{l}\text { Length of } \\
\text { school } \\
\text { day } \\
\text { (hours) } \\
(3)\end{array}$} & \multirow{2}{*}{$\begin{array}{c}\text { Share of } \\
\text { students } \\
\text { with } \\
\text { indigenous } \\
\text { languages } \\
\text { (4) }\end{array}$} & \multirow{2}{*}{$\begin{array}{l}\text { Schools } \\
\text { teaches in } \\
\text { indigenous } \\
\text { languages } \\
\quad(5)\end{array}$} & \multirow{2}{*}{$\begin{array}{l}\text { Proportion } \\
\text { of girls } \\
\text { in the } \\
\text { school } \\
\text { (6) }\end{array}$} & \multicolumn{3}{|c|}{ Passing rate } \\
\hline & $\begin{array}{c}\text { Juntos } \\
(1)\end{array}$ & $\begin{array}{l}\text { Crecer } \\
(2)\end{array}$ & & & & & $\begin{array}{l}\text { Boys } \\
(7)\end{array}$ & $\begin{array}{l}\text { Girls } \\
(8)\end{array}$ & $\begin{array}{l}\text { All } \\
(9)\end{array}$ \\
\hline $\begin{array}{l}\text { Mean of the } \\
\text { dependent variable }\end{array}$ & 0.470 & 0.762 & 5.68 & 0.375 & 0.113 & 43.1 & 0.665 & 0.721 & 0.691 \\
\hline \multicolumn{10}{|c|}{ Panel A. All schools } \\
\hline Section $>=8$ & $\begin{array}{c}-0.003 \\
{[0.020]}\end{array}$ & $\begin{array}{c}0.008 \\
{[0.018]}\end{array}$ & $\begin{array}{l}-0.028 \\
{[0.038]}\end{array}$ & $\begin{array}{c}-0.035 \\
{[0.025]}\end{array}$ & $\begin{array}{c}0.006 \\
{[0.017]}\end{array}$ & $\begin{array}{c}0.015 * * \\
{[0.007]}\end{array}$ & $\begin{array}{c}0.033 * * * \\
{[0.009]}\end{array}$ & $\begin{array}{c}0.031 * * * \\
{[0.009]}\end{array}$ & $\begin{array}{c}0.035 * * * \\
{[0.008]}\end{array}$ \\
\hline $\mathrm{N}$ & 8473 & 8473 & 8074 & 8067 & 8059 & 8473 & 8291 & 8379 & 8473 \\
\hline adj. R-sq & 0.649 & 0.506 & 0.059 & 0.355 & 0.136 & 0.059 & 0.238 & 0.161 & 0.211 \\
\hline \multicolumn{10}{|c|}{ Panel B. Only urban schools } \\
\hline Section $>=8$ & $\begin{array}{c}-0.037 \\
{[0.024]}\end{array}$ & $\begin{array}{l}-0.017 \\
{[0.029]}\end{array}$ & $\begin{array}{c}0.022 \\
{[0.065]}\end{array}$ & $\begin{array}{c}-0.019 \\
{[0.034]}\end{array}$ & $\begin{array}{c}0.008 \\
{[0.023]}\end{array}$ & $\begin{array}{c}0.006 \\
{[0.011]}\end{array}$ & $\begin{array}{c}0.006 \\
{[0.018]}\end{array}$ & $\begin{array}{c}0.015 \\
{[0.017]}\end{array}$ & $\begin{array}{c}0.011 \\
{[0.016]}\end{array}$ \\
\hline $\mathrm{N}$ & 4419 & 4419 & 4251 & 4247 & 4244 & 4419 & 4242 & 4334 & 4419 \\
\hline adj. R-sq & 0.645 & 0.523 & 0.033 & 0.262 & 0.089 & 0.037 & 0.219 & 0.225 & 0.233 \\
\hline \multicolumn{10}{|c|}{ Panel C. Schools with 7 or 8 sections } \\
\hline Section $>=8$ & $\begin{array}{c}0.022 \\
{[0.041]}\end{array}$ & $\begin{array}{c}0.022 \\
{[0.037]}\end{array}$ & $\begin{array}{c}0.038 \\
{[0.043]}\end{array}$ & $\begin{array}{c}-0.075 \\
{[0.056]}\end{array}$ & $\begin{array}{c}-0.042 \\
{[0.036]}\end{array}$ & $\begin{array}{l}-0.011 \\
{[0.009]}\end{array}$ & $\begin{array}{l}-0.002 \\
{[0.017]}\end{array}$ & $\begin{array}{c}-0.003 \\
{[0.016]}\end{array}$ & $\begin{array}{c}-0.004 \\
{[0.014]}\end{array}$ \\
\hline $\mathrm{N}$ & 571 & 571 & 543 & 543 & 542 & 571 & 566 & 570 & 571 \\
\hline adj. R-sq & 0.618 & 0.527 & 0.037 & 0.374 & 0.037 & 0.313 & 0.206 & 0.203 & 0.229 \\
\hline
\end{tabular}




\section{Table A5: Smoothness test at the student level}

Dependent variable:

\begin{tabular}{|c|c|c|c|c|c|c|}
\hline \multirow{2}{*}{\multicolumn{2}{|c|}{ Mother's characteristics }} & \multicolumn{5}{|c|}{ Student characteristics } \\
\hline & & \multirow{2}{*}{$\begin{array}{l}\text { Age in } \\
\text { years }\end{array}$} & \multirow{2}{*}{$\begin{array}{c}\text { Sex } \\
(\text { Girl }=1)\end{array}$} & \multirow{2}{*}{$\begin{array}{c}\text { Attended } \\
\text { kindergarten } \\
\quad(=1)\end{array}$} & \multicolumn{2}{|c|}{$\begin{array}{l}\text { Grade repetition } \\
\left(1^{\text {st }}-7^{\text {th }} \text { grade }\right)\end{array}$} \\
\hline $\begin{array}{l}\text { High } \\
\text { school } \\
\text { graduate or } \\
\text { more }(=1)\end{array}$ & $\begin{array}{c}\text { Speaks } \\
\text { Spanish } \\
(=1)\end{array}$ & & & & $\begin{array}{l}\text { Ever } \\
(=1)\end{array}$ & $\begin{array}{l}\text { Number of } \\
\text { grades }\end{array}$ \\
\hline
\end{tabular}

(1)

(2)

(1)

(2)

(5)

(6)

(7)

\begin{tabular}{|c|c|c|c|c|c|c|c|}
\hline \multirow[t]{2}{*}{ Section $\geq 8$} & -0.023 & 0.022 & -0.003 & -0.018 & -0.004 & 0.000 & 0.002 \\
\hline & [0.019] & [0.019] & [0.033] & [0.017] & [0.014] & {$[0.015]$} & [0.022] \\
\hline $\mathrm{N}$ & 13233 & 13222 & 13118 & 13499 & 13124 & 13067 & 13506 \\
\hline $\operatorname{adj} . R^{2}$ & 0.109 & 0.373 & 0.037 & 0.008 & 0.038 & 0.033 & 0.020 \\
\hline $\begin{array}{l}\text { Mean dep. } \\
\text { var. }\end{array}$ & 0.319 & 0.859 & 13.76 & 0.482 & 0.787 & 0.316 & 0.398 \\
\hline
\end{tabular}


Table A6: Robustness checks: Quadratic splines (2SLS)

\begin{tabular}{lcccccc}
\hline Sample: & All & Urban & $\begin{array}{c}\text { Morning } \\
\text { shift }\end{array}$ & $\begin{array}{c}\text { Urban and } \\
\text { morning }\end{array}$ & $\begin{array}{c}\text { All: } \\
\text { Diff in RD }\end{array}$ & $\begin{array}{c}\text { Urban: } \\
\text { Diff in } \\
\text { RD. }\end{array}$ \\
& $(1)$ & $(2)$ & $(3)$ & $(4)$ & $(5)$ & $(6)$ \\
\hline
\end{tabular}

Panel A. Dependent variable: Reading test scores

$\begin{array}{lcccccc}\text { JEC } & 0.137^{*} & 0.203 * & 0.080 & 0.126 & 0.112 & 0.170^{* *} \\ & {[0.083]} & {[0.107]} & {[0.066]} & {[0.078]} & {[0.069]} & {[0.083]} \\ & & & & & & \\ \text { N } & 360154 & 296063 & 189630 & 131337 & 360154 & 296063 \\ \text { Adj-R2 } & 0.262 & 0.192 & 0.315 & 0.262 & 0.263 & 0.194 \\ \text { F-stat } & 152.8 & 63.7 & 314.2 & 199.5 & 179.2 & 119.7\end{array}$

Panel B. Dependent variable: Reading Pr(grade level)

$\begin{array}{lcccccc}\text { JEC } & 0.032^{* *} & 0.049 * * & 0.020 & 0.032^{*} & 0.025^{*} & 0.040^{* *} \\ & {[0.015]} & {[0.024]} & {[0.013]} & {[0.018]} & {[0.013]} & {[0.019]} \\ \mathrm{N} & & & & & & \\ \text { Adj-R2 } & 360154 & 296063 & 189630 & 131337 & 360154 & 296063 \\ \text { F-stat } & 0.084 & 0.072 & 0.123 & 0.112 & 0.084 & 0.073\end{array}$

Panel C. Dependent variable: Math test scores

$\begin{array}{lcccccc}\text { JEC } & 0.260^{* * *} & 0.255^{* *} & 0.166^{* *} & 0.134 & 0.204^{* * *} & 0.186^{* *} \\ & {[0.086]} & {[0.120]} & {[0.069]} & {[0.086]} & {[0.072]} & {[0.091]} \\ \mathrm{N} & & & & & & \\ \text { Adj-R2 } & 360076 & 295986 & 189609 & 131316 & 360076 & 295986 \\ \text { F-stat } & 0.196 & 0.161 & 0.241 & 0.209 & 0.198 & 0.163\end{array}$

Panel D. Dependent variable: Math $\operatorname{Pr}($ grade level)

\begin{tabular}{lcccccc} 
JEC & $0.051 * * *$ & $0.072 * * *$ & $0.034 * * *$ & $0.043 * * *$ & $0.041 * * *$ & $0.052 * * *$ \\
& {$[0.015]$} & {$[0.021]$} & {$[0.012]$} & {$[0.015]$} & {$[0.013]$} & {$[0.016]$} \\
N & & & & & & \\
Adj-R2 & 360076 & 295986 & 189609 & 131316 & 360076 & 295986 \\
F-stat & 0.055 & 0.052 & 0.075 & 0.074 & 0.056 & 0.054 \\
\hline
\end{tabular}

Note: Robust standard clustered at the school district are shown in brackets. Each column reports 2SLS estimates using the discontinuity at 8 sections and with quadratic splines. Columns 5 and 6 do not include splines and are estimated using differences in discontinuities. F-stat refers to the instrument in the first stage. $* \mathrm{p}<0.10,{ }^{* *} \mathrm{p}<0.05, * * * \mathrm{p}<0.01$ 
Table A7. Additional robustness checks: Impact of JEC using differences-in-discontinuity (2SLS)

\begin{tabular}{lcc}
\hline Sample: & All & Urban \\
& $(1)$ & $(2)$ \\
\hline
\end{tabular}

Panel A. Dependent variable: Reading test scores

$\begin{array}{lcc}\text { JEC } & 0.121 * * * & 0.230^{* * *} \\ & {[0.042]} & {[0.058]} \\ \text { N } & 360154 & 296063 \\ \text { R2-adjust. } & 0.262 & 0.192 \\ \text { F-stat } & 254.1 & 167.3 \\ & & \\ \text { Panel B. Dependent variable: Reading } \operatorname{Pr}(\text { grade level) } \\ \text { JEC } & 0.033^{* * *} & 0.054^{* * *} \\ & {[0.008]} & {[0.014]} \\ & & \\ \text { N } & 360154 & 296063 \\ \text { R2-adjust. } & 0.084 & 0.072 \\ \text { F-stat } & 254.1 & 167.3\end{array}$

Panel C. Dependent variable: Math test scores

\begin{tabular}{lcc} 
JEC & $0.208 * * *$ & $0.289 * * *$ \\
& {$[0.048]$} & {$[0.071]$} \\
N & 360076 & 295986 \\
R2-adjust. & 0.197 & 0.160 \\
F-stat & 254.0 & 167.2 \\
& & \\
Panel D. Dependent variable: Math $\operatorname{Pr}($ grade level) \\
JEC & $0.047 * *$ & $0.069 * * *$ \\
& {$[0.010]$} & {$[0.015]$} \\
N & 360076 & 295986 \\
R2-adjust. & 0.056 & 0.052 \\
F-stat & 254.0 & 167.2 \\
\hline
\end{tabular}


Table A8. Datasets used in the mechanism analysis

\begin{tabular}{lcc}
\hline Name of dataset & $\begin{array}{c}\text { Year of data } \\
\text { collection }\end{array}$ & $\begin{array}{c}\text { Unit of } \\
\text { observation }\end{array}$ \\
\hline $\begin{array}{l}\text { Young Lives } \\
\text { (math and reading test scores, }\end{array}$ & 2016 & Child \\
$\begin{array}{l}\text { socio-emotional outcomes, } \\
\text { technical skills) }\end{array}$ & & \\
$\begin{array}{l}\text { Encuesta Nacional a Docentes } \\
\text { (time use of teachers) }\end{array}$ & 2016 & Teacher \\
$\begin{array}{l}\text { Semáforo Escuela } \text { (school } \\
\text { infrastructure including staff, } \\
\text { IT, pedagogical programs and } \\
\text { teacher's characteristics }\end{array}$ & 2016 & $\begin{array}{c}\text { Schools } \\
\text { and } \\
\text { teachers }\end{array}$ \\
\hline
\end{tabular}


Table A9: Descriptive statistics of the Young Lives sample

\begin{tabular}{l|c|cc|cc}
\hline Sample Characteristics & $\begin{array}{c}\text { Balanced } \\
\text { panel } \\
(1)\end{array}$ & $\begin{array}{c}\text { JEC } \\
(2)\end{array}$ & $\begin{array}{c}\text { Non-JEC } \\
(3)\end{array}$ & $\begin{array}{c}\text { Treated } \\
\text { group } \\
(4)\end{array}$ & $\begin{array}{c}\text { Control } \\
\text { Group } \\
(5)\end{array}$ \\
\hline Sex is female (\%) & 50 & 47 & 52 & 44 & $52^{* * *}$ \\
Age in years & 14.5 & 14.4 & 14.5 & 14.4 & 14.5 \\
Maternal Education Level & & & & & \\
$\quad$ Primary incomplete or less (\%) & 27 & 38 & $23 * * *$ & 42 & $28^{* * *}$ \\
Complete Primary or Secondary (\%) & 61 & 52 & $65^{* * *}$ & 49 & $65^{* * *}$ \\
Higher Education (\%) & 12 & 9 & $13 *$ & 8 & 7 \\
Wealth Index & & & & & \\
$\quad$ Tercile 1 (\%) & 32 & 44 & $27 * * *$ & 45 & $33 * * *$ \\
Tercile 2 (\%) & 34 & 39 & $31 * * *$ & 41 & $34 * *$ \\
$\quad$ Tercile 3 (\%) & 35 & 16 & $42^{* * *}$ & 14 & $32^{* * *}$ \\
Maternal tongue is not Spanish (\%) & 30 & 38 & $27 * * *$ & 44 & $31^{* * *}$ \\
Household located in urban area (\%) & 69 & 59 & $73 * * *$ & 55 & $66^{* * *}$ \\
Observations & 1558 & 439 & 1119 & 326 & 843 \\
\hline
\end{tabular}

Note: a t-test for differences in means is reported in column (III) for the comparison between columns (II) and (III), and column (V) for the comparison between columns (IV) and (V), ${ }^{*} \mathrm{p}<0.1, * * \mathrm{p}<0.05, * * * \mathrm{p}<0.01$. 
Table A10: Parental behavior with respect to students' coursework (2SLS)

\begin{tabular}{lccccc}
\hline $\begin{array}{l}\text { Dependent } \\
\text { variable: }\end{array}$ & $\begin{array}{c}\text { Student talks } \\
\text { to parents }\end{array}$ & Parents help & $\begin{array}{c}\text { Parents } \\
\text { explain } \\
\text { topics } \\
(1)\end{array}$ & $\begin{array}{c}\text { Parents care } \\
\text { about grades }\end{array}$ & $\begin{array}{c}\text { Parents } \\
\text { recommend } \\
\text { books } \\
(5)\end{array}$ \\
\hline JEC & 0.006 & $0.034^{*}$ & -0.021 & 0.020 & $-0.041^{* *}$ \\
& {$[0.022]$} & {$[0.020]$} & {$[0.022]$} & {$[0.017]$} & {$[0.019]$} \\
N & 287194 & 286529 & 285389 & 285136 & 285265 \\
R2-adjust. & 0.023 & 0.026 & 0.038 & 0.031 & 0.024 \\
F-stat & 219.0 & 219.0 & 217.4 & 218.4 & 218.6 \\
Mean & 0.455 & 0.292 & 0.413 & 0.811 & 0.599 \\
\hline
\end{tabular}

Note: Robust standard clustered at the school district are shown in brackets. Each column reports 2SLS estimates using differences in discontinuity at 8 . The sample is limited to public schools in urban areas. $F$ stat refers to the instrument in the first stage. Mean refers to the average of the dependent variable.

$* \mathrm{p}<0.10, * * \mathrm{p}<0.05, * * * \mathrm{p}<0.01$. 
Table A11: Students' self-perceptions (2SLS)

\begin{tabular}{|c|c|c|c|c|c|c|c|c|c|c|}
\hline & $\begin{array}{c}\text { Understands } \\
\text { any topic } \\
\text { (1) } \\
\end{array}$ & $\begin{array}{c}\text { Learns } \\
\text { without } \\
\text { difficulty } \\
(2) \\
\end{array}$ & $\begin{array}{c}\text { Understand } \\
\text { hard topics } \\
\text { (3) }\end{array}$ & $\begin{array}{c}\text { Confident } \\
\text { on test } \\
(4) \\
\end{array}$ & $\begin{array}{c}\text { Helps } \\
\text { her/his } \\
\text { peers } \\
(5)\end{array}$ & $\begin{array}{c}\text { Does } \\
\text { homework } \\
\text { without help } \\
(6) \\
\end{array}$ & $\begin{array}{c}\text { Confident } \\
\text { on passing } \\
\text { course } \\
(7) \\
\end{array}$ & $\begin{array}{l}\text { Good at } \\
\text { solving } \\
\text { problems } \\
(8)\end{array}$ & $\begin{array}{c}\text { Feels } \\
\text { capable as } \\
\text { I learn } \\
(9)\end{array}$ & $\begin{array}{c}\text { Feels h/she } \\
\text { is good at } \\
\text { the subject } \\
(10)\end{array}$ \\
\hline \multicolumn{11}{|c|}{ Panel A. Perceptions about reading } \\
\hline JEC & $\begin{array}{c}-0.014 \\
{[0.017]}\end{array}$ & $\begin{array}{c}-0.033 \\
{[0.021]}\end{array}$ & $\begin{array}{l}-0.036 * \\
{[0.019]}\end{array}$ & $\begin{array}{c}-0.040 * * \\
{[0.018]}\end{array}$ & $\begin{array}{c}-0.013 \\
{[0.020]}\end{array}$ & $\begin{array}{c}-0.015 \\
{[0.021]}\end{array}$ & $\begin{array}{c}-0.033 * \\
{[0.018]}\end{array}$ & $\begin{array}{c}-0.048 * * \\
{[0.022]}\end{array}$ & $\begin{array}{c}-0.026 \\
{[0.019]}\end{array}$ & $\begin{array}{c}-0.026 \\
{[0.021]}\end{array}$ \\
\hline$N$ & 278307 & 282404 & 282986 & 281505 & 279835 & 282129 & 282342 & 282022 & 282260 & 282877 \\
\hline \multicolumn{11}{|c|}{ Panel B. Perceptions about math } \\
\hline JEC & $\begin{array}{c}-0.014 \\
{[0.024]}\end{array}$ & $\begin{array}{c}-0.012 \\
{[0.023]}\end{array}$ & $\begin{array}{c}0.005 \\
{[0.022]}\end{array}$ & $\begin{array}{c}0.018 \\
{[0.024]}\end{array}$ & $\begin{array}{c}-0.061 * * \\
{[0.025]}\end{array}$ & $\begin{array}{c}-0.030 \\
{[0.028]}\end{array}$ & $\begin{array}{c}0.020 \\
{[0.022]}\end{array}$ & $\begin{array}{c}-0.010 \\
{[0.025]}\end{array}$ & $\begin{array}{c}-0.002 \\
{[0.019]}\end{array}$ & $\begin{array}{c}-0.009 \\
{[0.024]}\end{array}$ \\
\hline$N$ & 285074 & 284009 & 281519 & 283751 & 283502 & 283679 & 282155 & 281325 & 281593 & 279529 \\
\hline
\end{tabular}

Note: Robust standard clustered at the school district are shown in brackets. Each column reports 2SLS estimates using differences in discontinuity at 8. The sample is limited to public schools in urban areas. $* \mathrm{p}<0.10, * * \mathrm{p}<0.05, * * * \mathrm{p}<0.01$. 
Table A12: Teachers' responses (2SLS)

\begin{tabular}{|c|c|c|c|c|c|c|c|c|}
\hline & \multicolumn{8}{|c|}{ Math and reading teachers combined: } \\
\hline & $\begin{array}{c}\text { Start class } \\
\text { explaining } \\
\text { what's ahead } \\
\text { (1) }\end{array}$ & $\begin{array}{l}\text { Start class with } \\
\text { summary of } \\
\text { previous lecture } \\
\text { (2) }\end{array}$ & $\begin{array}{l}\text { Use real } \\
\text { world } \\
\text { examples } \\
\text { (3) }\end{array}$ & $\begin{array}{c}\text { Use different } \\
\text { materials } \\
(4)\end{array}$ & $\begin{array}{c}\text { They relate topics } \\
\text { (5) }\end{array}$ & $\begin{array}{l}\text { Start class by } \\
\text { asking what } \\
\text { do we know } \\
(6)\end{array}$ & $\begin{array}{l}\text { Move too fast } \\
\text { to next topic } \\
\text { (7) }\end{array}$ & $\begin{array}{l}\text { Ask for our } \\
\text { arguments } \\
\text { and ideas } \\
(8)\end{array}$ \\
\hline JEC & $\begin{array}{c}-0.006 \\
{[0.018]}\end{array}$ & $\begin{array}{c}-0.012 \\
{[0.017]}\end{array}$ & $\begin{array}{c}-0.005 \\
{[0.018]}\end{array}$ & $\begin{array}{c}0.047 * * \\
{[0.021]}\end{array}$ & $\begin{array}{c}0.002 \\
{[0.018]}\end{array}$ & $\begin{array}{c}-0.008 \\
{[0.018]}\end{array}$ & $\begin{array}{c}0.000 \\
{[0.015]}\end{array}$ & $\begin{array}{c}0.024 \\
{[0.022]}\end{array}$ \\
\hline$N$ & 282258 & 281548 & 278013 & 278454 & 279613 & 278245 & 276299 & 275067 \\
\hline & $\begin{array}{l}\text { Demand } \\
\text { verbatim } \\
\text { responses } \\
(9) \\
\end{array}$ & $\begin{array}{l}\text { Make sure we } \\
\text { understood }\end{array}$ & $\begin{array}{c}\text { Supervise } \\
\text { we all } \\
\text { participate } \\
\\
(11) \\
\end{array}$ & $\begin{array}{l}\text { Leave comments } \\
\text { about how to } \\
\text { improve } \\
\text { (12) }\end{array}$ & $\begin{array}{c}\text { We receive } \\
\text { comments about } \\
\text { what did wrong } \\
\text { (13) }\end{array}$ & $\begin{array}{l}\text { Recognize our } \\
\text { errors and } \\
\text { explain } \\
\text { (14) } \\
\end{array}$ & $\begin{array}{c}\text { Give } \\
\text { suggestions on } \\
\text { how to learn } \\
(15) \\
\end{array}$ & $\begin{array}{c}\text { Explain what } \\
\text { we will learn } \\
\text { with } \\
\text { homework } \\
\text { (16) }\end{array}$ \\
\hline JEC & $\begin{array}{c}-0.021 \\
{[0.019]}\end{array}$ & $\begin{array}{c}0.011 \\
{[0.016]}\end{array}$ & $\begin{array}{c}-0.006 \\
{[0.017]}\end{array}$ & $\begin{array}{c}-0.016 \\
{[0.021]}\end{array}$ & $\begin{array}{c}-0.012 \\
{[0.022]}\end{array}$ & $\begin{array}{c}0.003 \\
{[0.017]}\end{array}$ & $\begin{array}{c}-0.017 \\
{[0.016]}\end{array}$ & $\begin{array}{c}-0.008 \\
{[0.018]}\end{array}$ \\
\hline$N$ & 274432 & 277826 & 276131 & 274650 & 275711 & 276078 & 276367 & 276799 \\
\hline
\end{tabular}

Note: Robust standard clustered at the school district are shown in brackets. Each column reports 2 SLS estimates using differences in discontinuity at 8 . The sample is limited to public schools in urban areas. $* \mathrm{p}<0.10, * * \mathrm{p}<0.05, * * * \mathrm{p}<0.01$. 
Figure A1: Comparing estimates from JEC against recent randomized studies in education

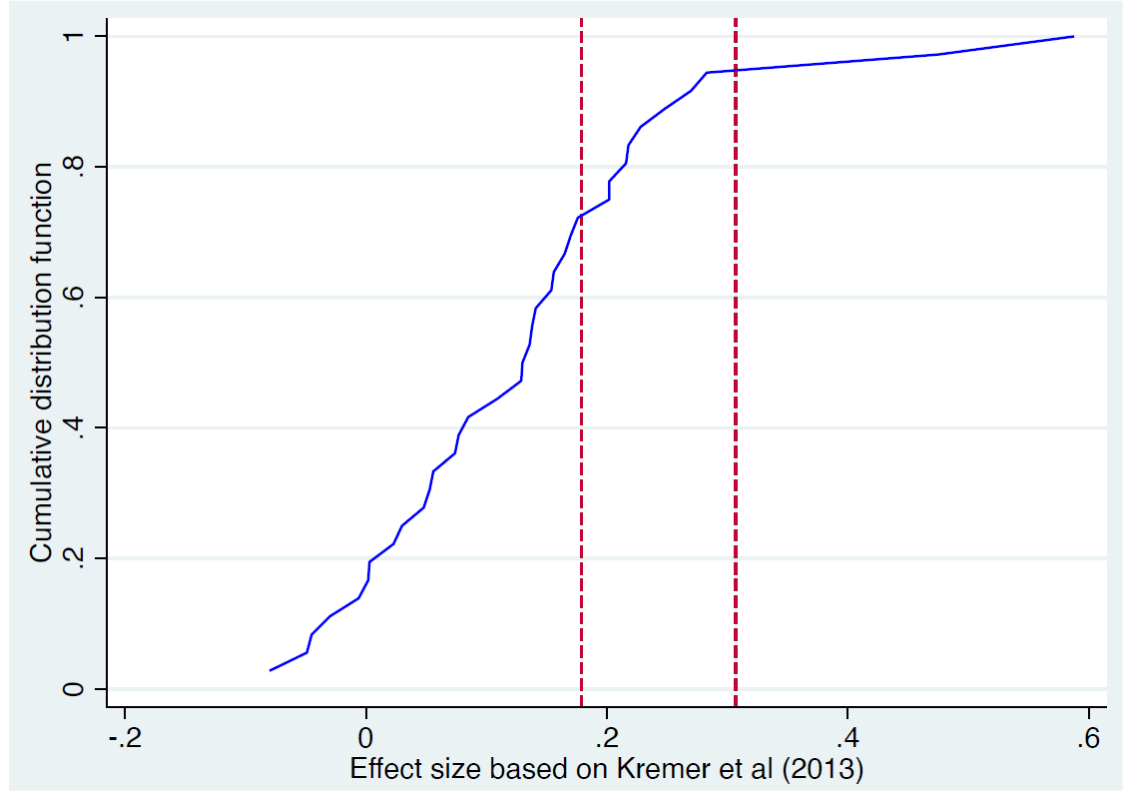

Note: The dashed vertical lines represent the range of estimates of the impact of JEC for math test scores as reported Table 2, Panel C (0.179-0.307). The CDF was obtained from the reported effect sized in Kremer et al (2013) from recent randomized controlled trials on education in developing countries. 
Figure A2: Robustness check: Stochastic dominance (reduced form)
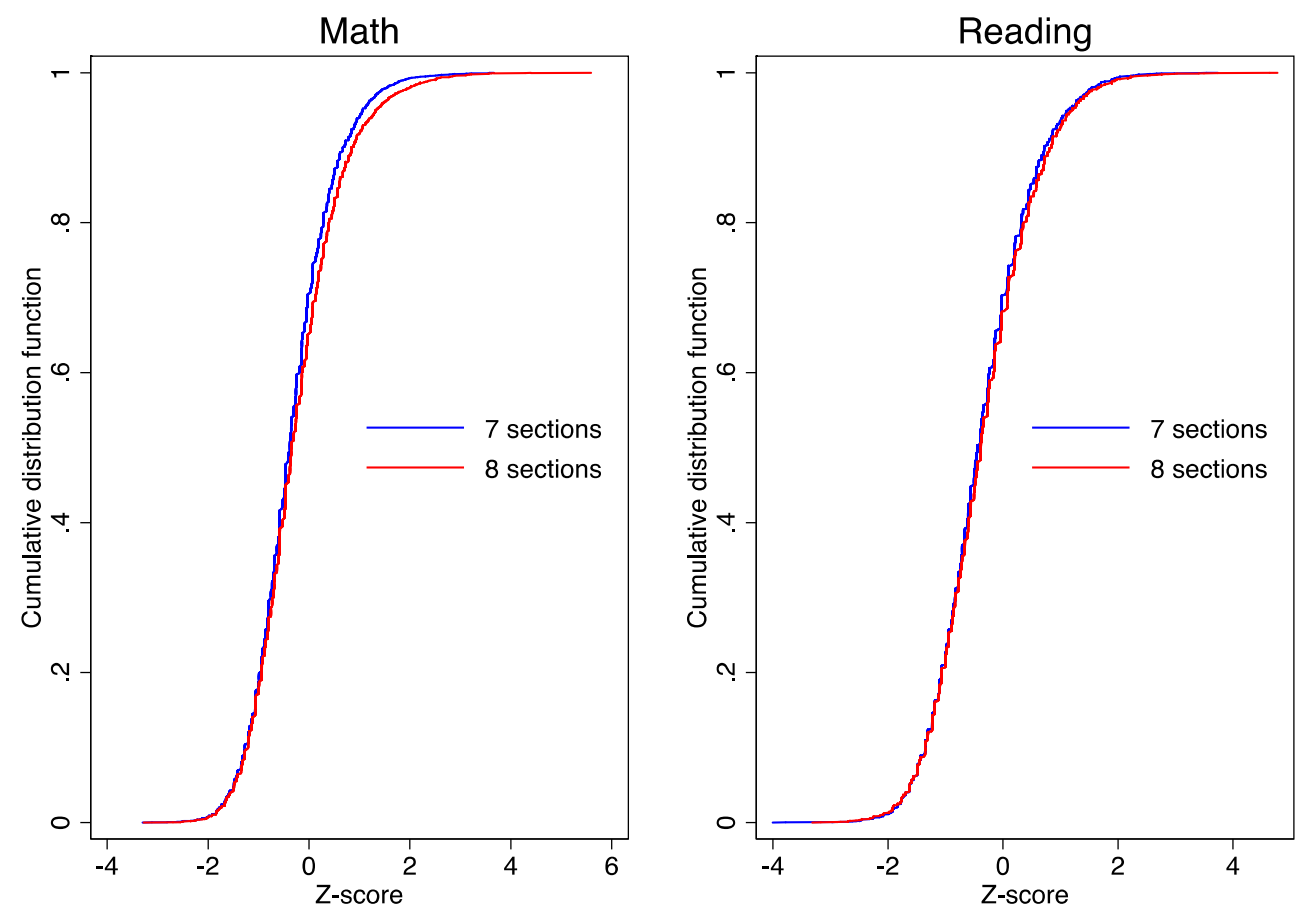

Note: CDF functions estimated separately for students in public schools with seven and eight sections. Data source: 2015 ECE-S. 
Figure A3: Participation in JEC by section and type of shift

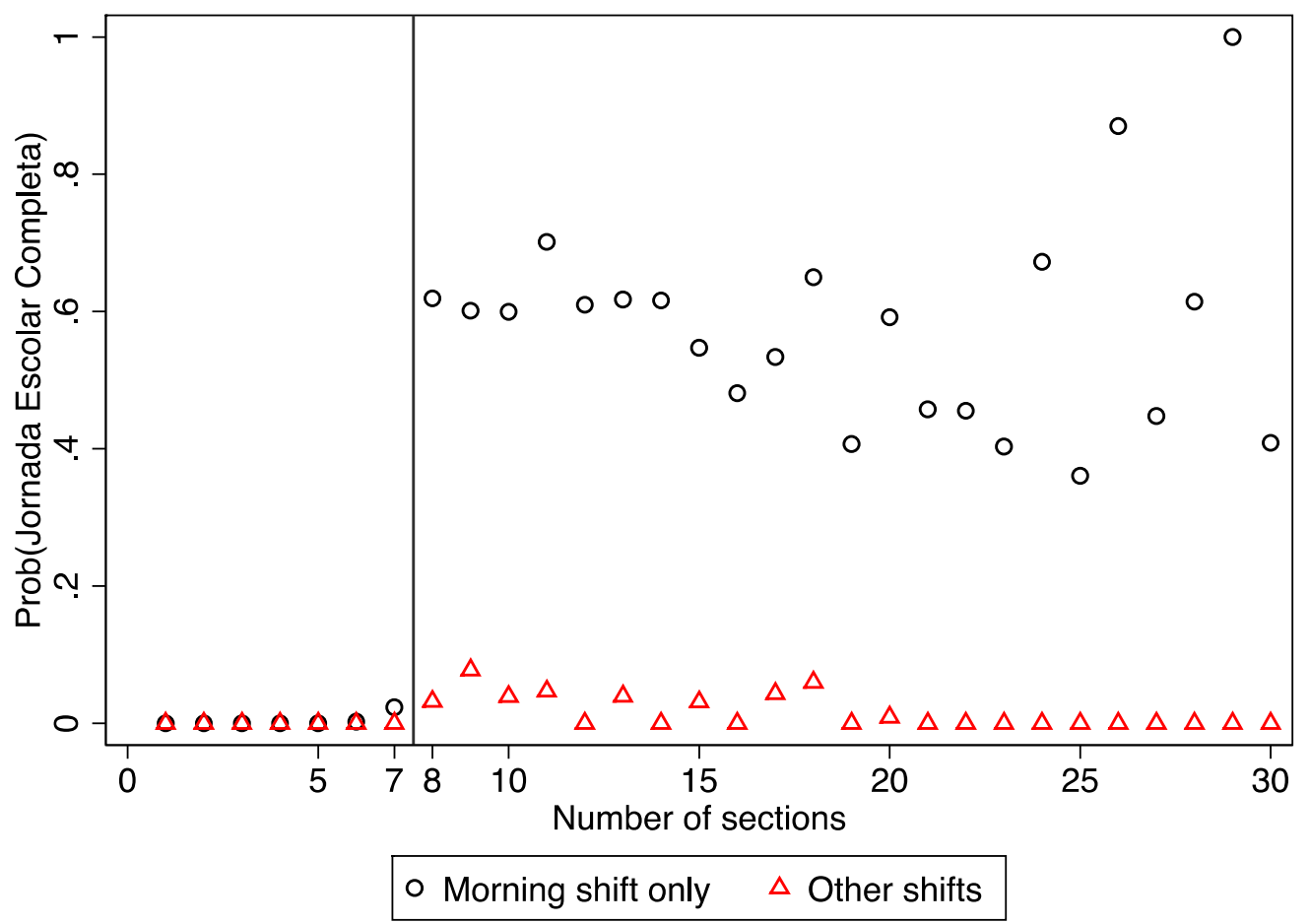

Note: Each circle represents the share of schools that belong to JEC by their number of sections. Sample includes all public high schools. Source: Author's calculation based on 2013 Censo Escolar. 
Figure A4: Placebo test: number of sections and test scores for private schools (reduced form)
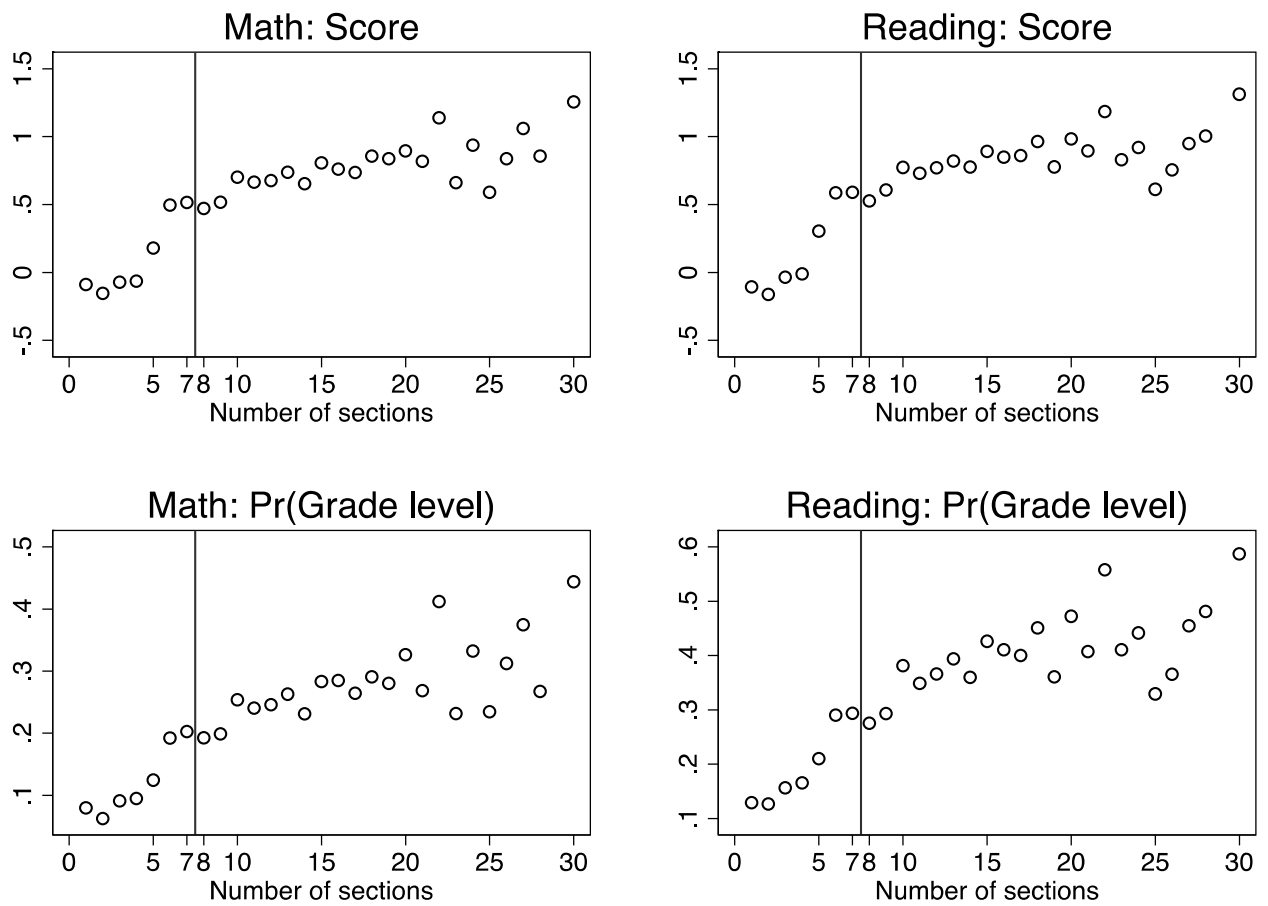

Note: Each symbol represents the sample average by section. Sample includes private schools only. Data source: 2015 ECE-S. 
Figure A5: Parental behavior (reduced form)
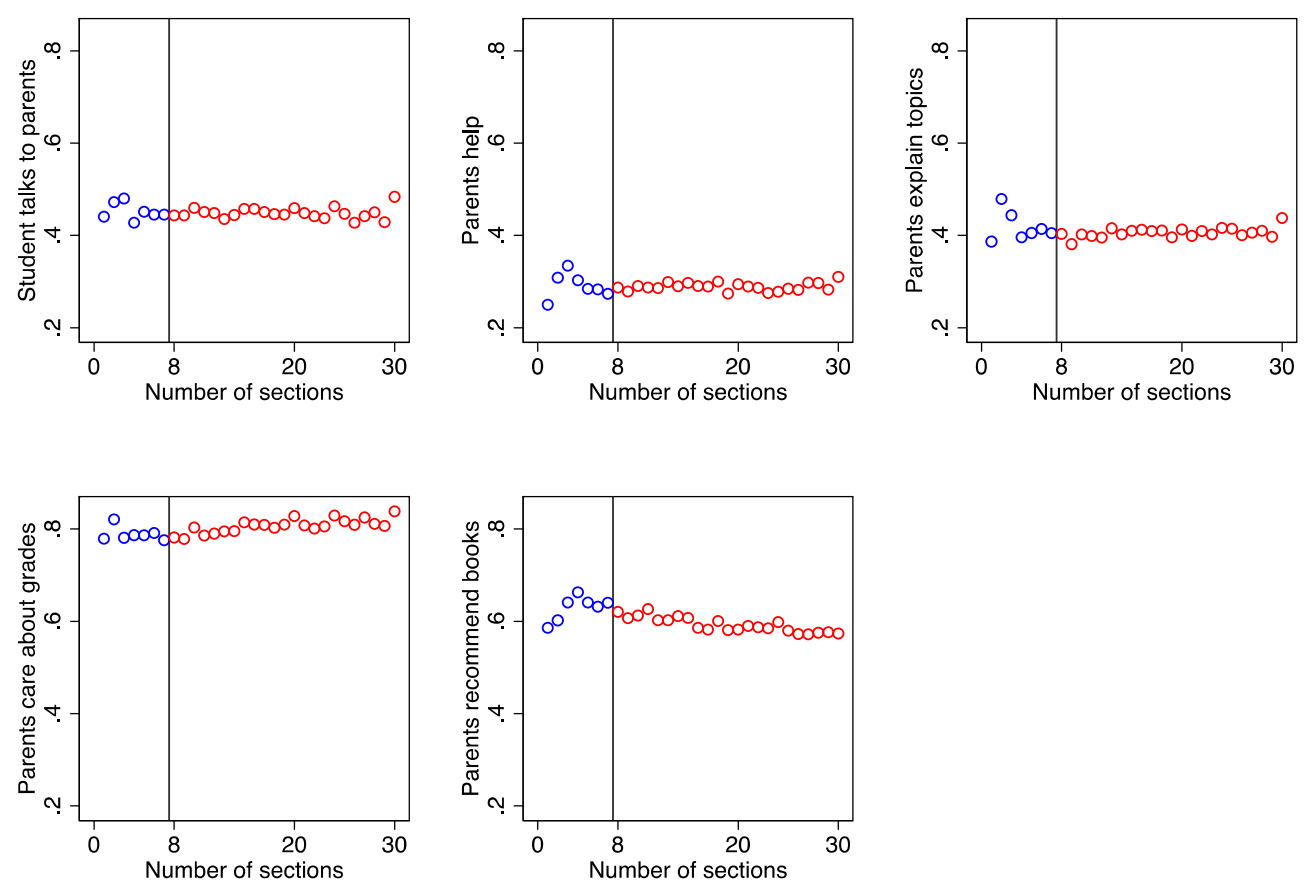

Note: Each symbol represents the sample average by section. Sample is restricted to public schools in urban areas. Data source: 2015 ECE-S. 
Figure A6 Students' behavior (reduced form)

Panel A. Attitudes towards reading
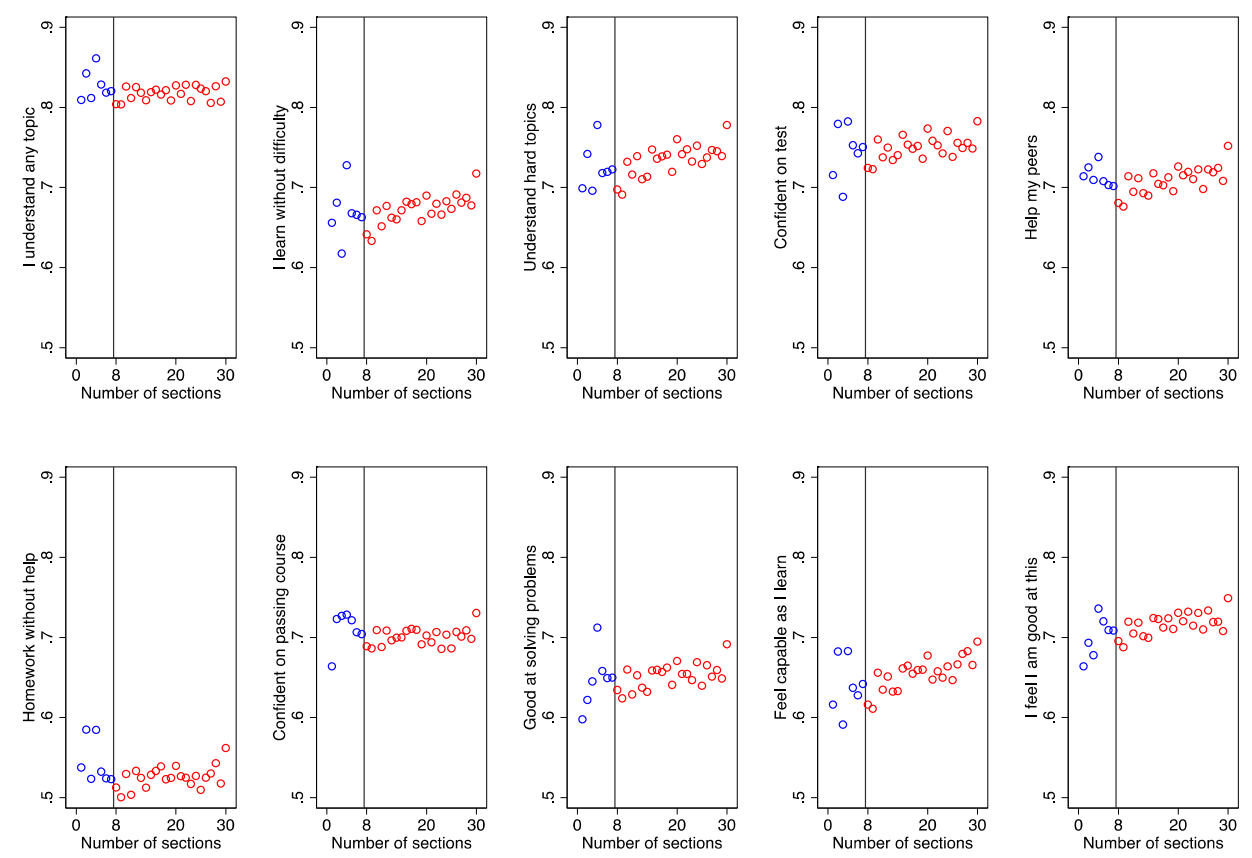

Panel B. Attitudes towards math
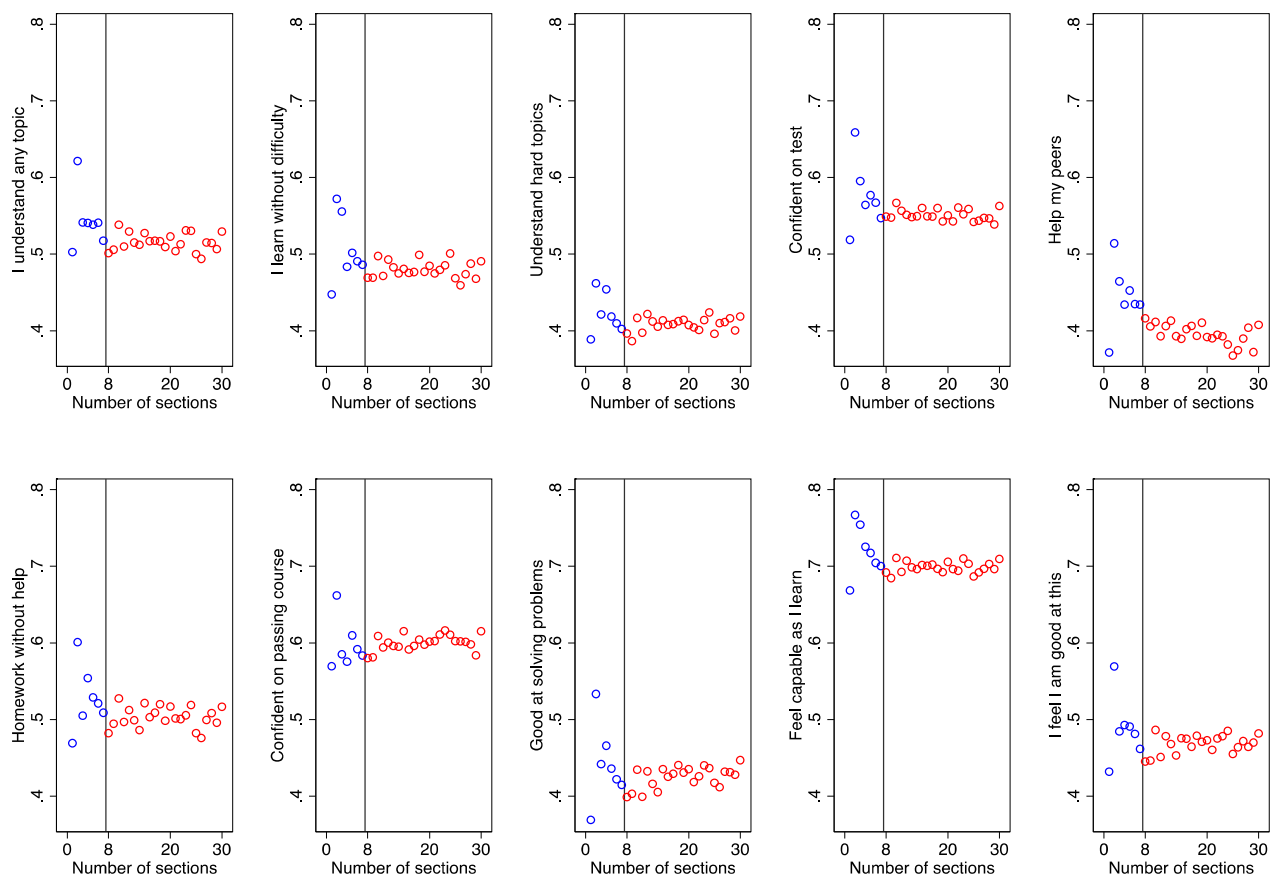

Note: Each symbol represents the sample average by section. Sample is restricted to public schools in urban areas. Data source: 2015 ECE-S. 
Figure A7. Teachers' behavior (reduced form)
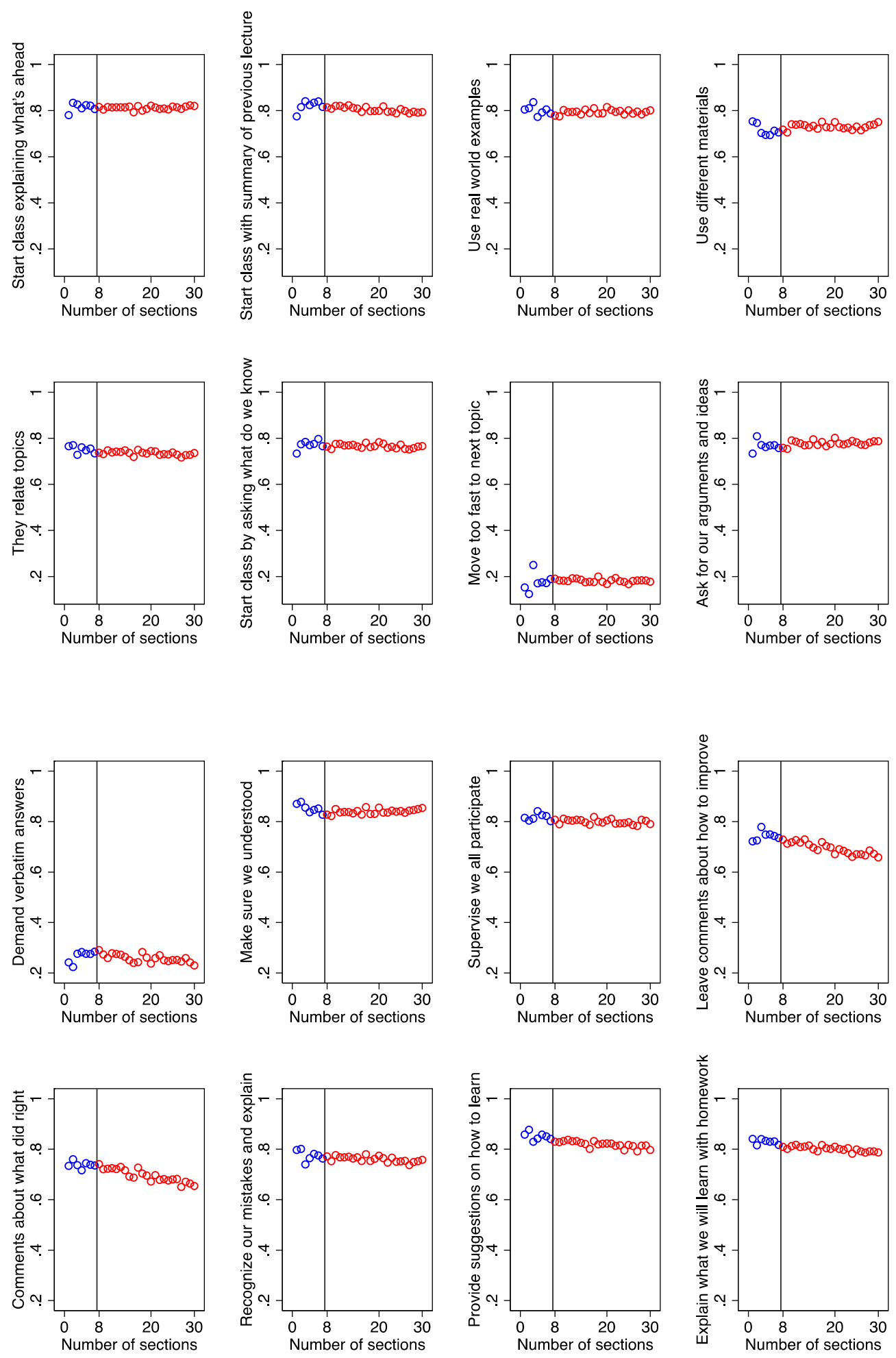

Note: Each symbol represents the sample average by section. Sample is restricted to public schools in urban areas. Data source: 2015 ECE-S. 